\title{
STRENGHTENING LABOUR AND EMPLOYMENT RIGHTS FOR ILLEGALIZED WORKERS
}

by

Fabiola Limon Bravo, BA (Honours), University of Ontario Institute of Technology, 2014

\author{
A Major Research Paper \\ presented to Ryerson University \\ in partial fulfillment of the requirements for the degree of \\ Master of Arts \\ in the Program of \\ Immigration and Settlement Studies
}

Toronto, Ontario, Canada, 2016

(C) Fabiola Limon Bravo 2016 


\section{AUTHOR'S DECLARATION FOR ELECTRONIC SUBMISSION OF A MAJOR RESEARCH PAPER (MRP)}

I hereby declare that I am the sole author of this Major Research Paper. This is a true copy of the MRP, including any required final revisions, as accepted by my examiners.

I authorize Ryerson University to lend this MRP to other institutions or individuals for the purpose of scholarly research

I further authorize Ryerson University to reproduce this MRP by photocopying or by other means, in total or in part, at the request of other institutions or individuals for the purpose of scholarly research.

I understand that my MRP may be made electronically available to the public.

Fabiola Limon Bravo 


\title{
STRENGHTENING LABOUR AND EMPLOYMENT RIGHTS FOR ILLEGALIZED WORKERS
}

Fabiola Limon Bravo

Master of Arts 2016

Immigration and Settlement Studies

Ryerson University

\begin{abstract}
This major research paper (MRP) takes a critical perspective on the neo-liberal policies that are generating illegalized immigrants, notably the temporary foreign workers program. The state is fully aware that these policies are generating a pool of flexible and exploitable illegalized workers. In order to show the public that it is controlling the "illegal" immigration phenomenon, the state continues to uphold strict border patrol and immigration laws. However, state tactics are merely for show, as most illegalized immigrants originally enter through legal avenues. Many illegalized immigrants are forced into the underground workforce, which makes them vulnerable to exploitation by employers. Although Toronto is a Sanctuary City and provides access to illegalized immigrants, it cannot fully protect them from workplace violations, as labour and employment rights are under provincial jurisdiction. Thus, Ontario should become a Sanctuary Province, in order to provide equitable employment to illegalized workers.
\end{abstract}

Key Words: Neo-liberalism, Temporary Foreign Workers Program, Illegalized Immigrants, Sanctuary City, Labour and Employment Rights 


\section{Acknowledgements}

First, I would like to thank Graham Hudson for being my supervisor and providing me with constructive feedback throughout my writing process. His knowledge and support helped me complete my MRP. Thank you for guiding me throughout this entire process. I would also like to thank Henry Parada. It has been a privilege to be your student, be part of your research project, as well as having you as my second reader. Finally, I would like to thank my family and friends for supporting me throughout my entire academic journey. In particular, I would like to thank my mom. I could not have completed this journey without your love and support. Thank you for preparing me delicious snacks and coffee, while I worked on my MRP! 


\section{Table of Contents}

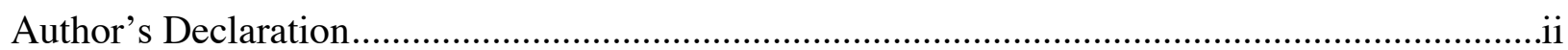

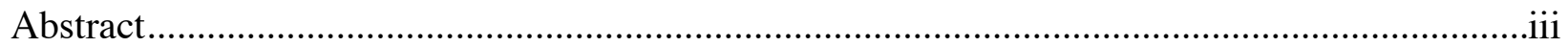

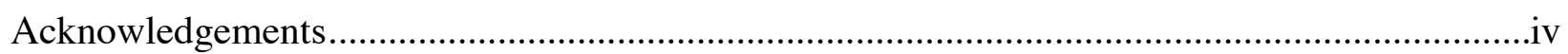

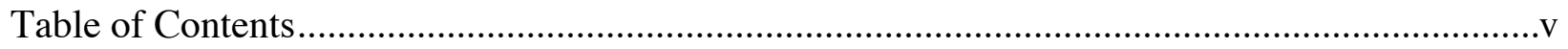

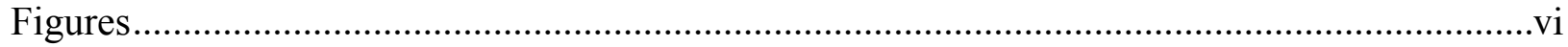

\section{PART I}

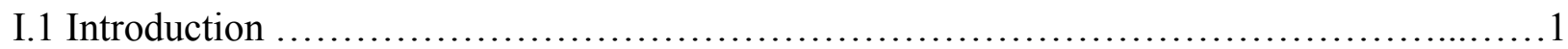

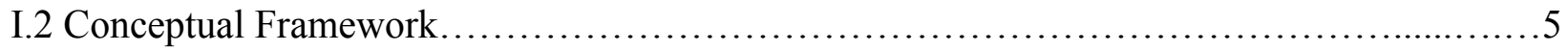

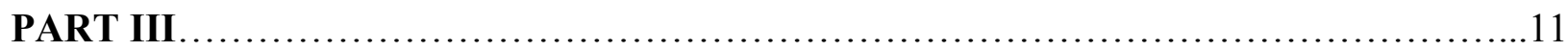

II.1 A Lack of Exit Controls.............................................................. 13

II.2 Operational Definitions.......................................................... 15

II.3 The Process of Illegalization....................................................... 17

II.4 Working Conditions for Illegalized Workers...................................... 21

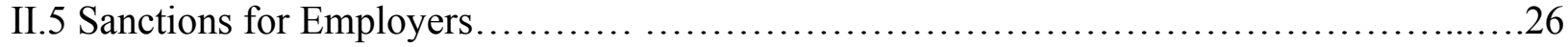

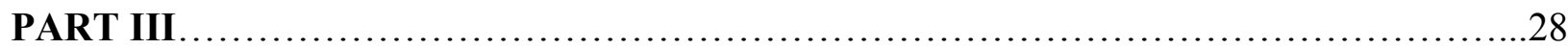

III.1 The TFWP, the Illegalization of Temporary Workers and Semi-Solution .................28

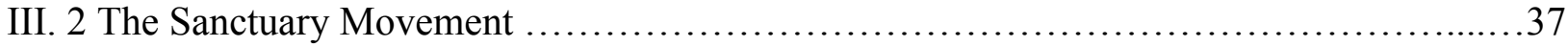

\section{PART IV}

IV. 1 Labour and Employment Rights and Recommendations ..........................40

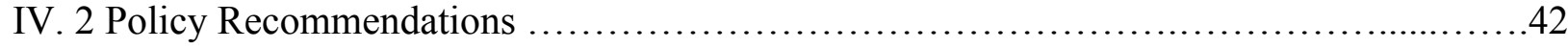

\section{PART V}

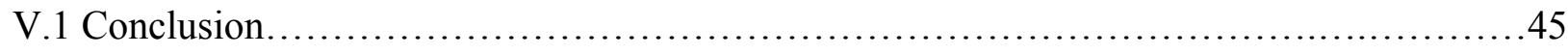

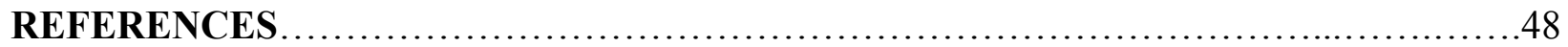




\section{Figures}

Figure I: Number of temporary residents in Canada by category, $1988-2012 \ldots \ldots \ldots \ldots \ldots \ldots . . . . .32$

Figure II: Permanent and Temporary (Non-Visitor Landing into Toronto)....................33

Figure III: Temporary Resident Entries (Non-Visitors) by Location (2011) ..................34

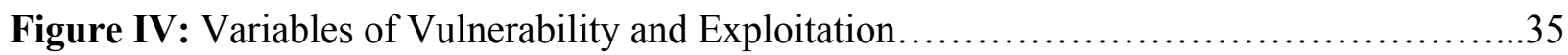




\section{PART I}

\section{1 Introduction}

In 1983, a man, his pregnant wife and three young children trespassed onto my grandmother's vacant property in México, in order to seek shelter. The neighbor informed my grandmother. At first, she asked them to leave, but after the man pleaded with her, she granted them temporary permission to stay-- until she sold the property. She had two conditions, however. The man had to maintain the property, and he had to ensure that no other person trespassed. A couple of months later, the man invited his parents to move into the house. When my grandmother found out, she asked the family to move out. With nowhere to go and as the man felt that they had a right to stay, he attained a lawyer. He pursued ownership of the property. The story is twofold: The man and his family do not have a formal right to stay on or a formal right to the property, but, nonetheless, they still have human rights. Whether they can exercise these rights depends on whether they are in a position to exercise them.

In the past, I have shared this personal story with my colleagues, and it conjures a mix of emotions. Many colleagues have asked "did the man and his family keep the property?" As I am often reluctant to share the ending of the story, I simply will refrain from sharing it now. The sole purpose of the story is to spark a debate regarding "illegal" migration. For the purpose of this MRP, the story will be used as a micro-level analogy, in order to depict the macro-level realties within the immigration system in Canada. Borders are often disconnected from everyday realities. By sharing a micro-level analogy, the reader may be able to resonate with illegalized immigrants. Although it is reasonable to assume that people will have mixed opinions regarding "illegal" migration, there are two factor that every person should agree upon.

Regardless of a person's status, he or she should not be exploited or stripped of human rights. 
In Canada, most illegalized migrants arrive vis-à-vis legal avenues, but often surpass their tourist, student or work permit (Bauder \& Shields, 2015; Brillinger, 2015; Nyers, 2010; Khandor et al., 2004). A myriad of factors may influence a person to stay, which may lead to the illegalization of a person. Migrants also enter a country without authorization. Inequalities perpetrate the decision of many illegalized immigrants to seek economic opportunities, notably in the Global North (Carens, 1987) and others seek family reunification (Bauder \& Shields, 2015). Migrating to a new country, whether "legally" or "illegally," is not always a fully voluntary choice (Carens, 1987).

Nevertheless, keeping people out and having a bureaucratic system to determine who can be a member of a society is a key characteristic of a sovereign society and the prerogative of a political community (Carens, 1987). The advent of globalization has resulted in the use of immigration law as a mechanism to defend sovereignty (Dauverge, 2008). Federal immigration policy is used as a tool to regulate who can come in and who has to stay out (Bauder \& Shields, 2015). The process that is used to determine who is deemed desirable is selective, and it is shaped by the government's perception of the population's needs, including economic, cultural and demographic (Siemiatycki, 2015). In order to achieve the state's self-interest, Canada has not always exercised generosity and humanitarianism (Siemiatycki, 2015).

Immigration law also servers as a mechanism to dictate a person's political, legal, social and economic rights (Khandor et al., 2004). Being born within the borders of an affluent Western country may provide an individual with certain rights and entitlements, whereas being born on the other side of a border may force a person to live in poverty or political instability. If a person transcends a border "illegally," he or she does not obtain political membership within a state, but it does not imply that the person cannot be part of a community. It also does not imply that the 
illegalized person will have no rights. For example, in Ontario, the Employment Standard Act protects non-unionized workers, which in theory covers illegalized workers (Workers Action Centre, 2011). However, illegalized workers fear deportation, if they attempt to exercise their rights, due to (Workers Action Centre, 2011). In other words, illegalized workers have basic labour and employment rights, but in practice they cannot exercise those rights.

Further, being a member of a community and having a political membership are two separate entities. That is, illegalized workers may not obtain political membership, but that does not mean that they are not paying taxes, raising families and working (Khando et. Al, 2004). In fact, most illegalized immigrants have jobs (Khando et. Al, 2004). They contribute to their communities in a myriad of ways (Khando et. Al, 2004). Illegalized immigrants are active members of society. If a community member [whether "illegal" or legal"] is contributing to the community, then equitable labour and employment rights ought to fully protect the worker. Knowledge, access and a sanctuary are all interlinked with an illegalized worker's ability to be able to exercise his or her rights.

The lack of status renders illegalized immigrants vulnerable to exploitation by employers for the fruits of their labour (Hannan, 2013). Employers also benefit from illegalized workers, as they cannot make demands (Hannan, 2013). They are susceptible to unfair and dangerous working conditions, and they are not eligible for worker's compensation, if he or she is injured at work (Khandor et al., 2004). As a result of a work place injury, illegalized workers are unlikely to seek medical attention (Berinstein, et al., 2006). They are paid below federal and provincial minimum wage, work long hours (with no overtime pay), live in crowded accommodations, work in unsafe conditions, and they have limited resources in the event of abuse at work (Hannan 2013; Goldring, Berinstein \& Bernhard, 2009). 
The omnipresence and exploitation of illegalized immigrants sparked activists to advocate for a Sanctuary City policy in Toronto (No One is Illegal, 2016; the Social Planning Toronto, 2013). In 2013 and 2014, respectively, Toronto and Hamilton were declared Sanctuary cities (No One is Illegal, 2016). In general, Sanctuary cities address a myriad of issues that illegalized immigrants encounter on a day-to-day basis, notably access to municipal services (No One is Illegal, 2016). However, they fail to address other profound issues, such as labour and employment rights. In Ontario, although some labour and employment rights "extend" to illegalized workers (Workers Action Centre, 2011), they cannot fully exercise their rights. As labour rights are under provincial jurisdiction, there ought to be reforms at the provincial level. Activists and researchers have started to advocate for a Sanctuary Province in Ontario (No One is Illegal, 2016; Hannan \& Bauder, 2015). This, in turn, could also extend access to illegalized immigrants in neighboring cities and secure labour and employment rights for every worker, irrespective of his or her immigration status.

This paper argues that federal immigration policy is producing illegalized immigrants. Recent changes to the Temporary Foreign Workers Program (TFWP) will increase the omnipresence of illegalized workers in Canada. The state and some industries and businesses benefit from having a pool of cheap and flexible workers who, in turn, become easily exploitable (Siemiatycki, 2015). Some argue that the state knows that it is producing irregularity and, indeed, may well do so intentionally (De Genova, 2013). Although the state is generating illegalized immigrants for economic purposes (Bauder, 2013), they continue to exclude illegalized immigrants from the political community. Illegalized immigrants are suitable enough work, but not suitable enough to become permanent residents and citizens. Paradoxically, the state uses strict immigration law to deter and control "illegal" migration. By demonstrating strict law 
enforcement, the public undermines the state's role in the illegalization process (De Genova, 2013). Nevertheless, they are the creators and the drivers of the underground workforce.

Political movements are challenging the state's power to structure discourses in this area around traditional binaries, such as citizens/non-citizens (Nyers, 2010). Although the movements have been successful in achieving a Sanctuary City, reforms at the provincial level ought to be made in order to ensure that every worker can fully exercise his or her labour and employment rights. As the federal government obtains absolute constitutional authority, municipal and provincial policies cannot contradict federal laws (Shields, 2004). This means that any reforms at these levels that seek to provide concrete rights to illegalized workers, must respect federal laws. Reforms are imperative in order to protect illegalized workers from exploitation and counteract the by-products of neoliberalism capitalism.

\section{2 Conceptual Framework}

This MRP will take a critical perspective on the neoliberal policies that illegalize migrants, which, in turn, prevents them from having full rights to and within the political community. A lack of full protection from the law, as well as a space where illegalized immigrants are unable to exercise their rights means that the exploitation of illegalized immigrants has become the norm. On the one hand, the neoliberal rhetoric is not concerned with protecting illegalized immigrants, but on the other, it seeks to attract illegalized immigrants for the market and cheap labour (Bauder, 2014). It is fundamental to address these profound issues, as recent changes to federal immigration policy is expected to increase the number of illegalized immigrants. ${ }^{1}$ In accordance with the immigration policy reforms, temporary workers are suitable

\footnotetext{
${ }^{1}$ Note: The 4-in-4-out rule will be explained in the following section. It is a recent change to the Temporary Foreign Worker's Program, which will increase the number of illegalized workers in Canada. The strict immigration policy is aligned with neoliberal values.
} 
for labour; however, they are not suitable enough to possess full labour and employment protection nor a membership to the Canadian political community. Consequently, immigration policies are generating a greater number of illegalized immigrants by not providing them with a pathway to citizenship. Temporary workers are surpassing their work visas and entering the underground workforce. As these workers become illegalized, their contribution to society continues to be highly undervalued, as well as undermined by the state (Bauder, 2013).

In order to critique the neo-liberal policies that are illegalizing migrants, a human rights approach will be used. The framework will be used to validate the critique, as every person possesses human rights, irrespective of his of her immigration status (Kallen, 2003). This includes the right to education, non-discrimination, medical care, shelter, as well as labour and employment rights (The United Nations, 1948). More specifically, every person has the right to adequate working conditions and equivalent remuneration for equivalent labour (The United Nations, 1948). Human right principles are the standard at which every person should be treated (Kallen, 2003). Nevertheless, the neoliberal rhetoric often rejects these principles. This can be demonstrated via the exclusion of illegalized immigrants from the medial system. As a result, illegalized immigrants are unlikely to seek medical attention, if he or she is injured at work (Berinstein, et al., 2006). In accordance with the Universal Declaration of Human Rights: “...no distinction shall be made on the basis of the political, jurisdiction or international status of the country of territory to which a person belongs... (The United Nations, 1948, par. 10)" As every human being possesses human rights, neoliberal policies should be inclusionary instead of proactively excluding illegalized immigrants from the political community.

To begin, neoliberalism is strictly driven by market values (Harvey, 2007). It proposes that human well-being can be achieved by the privatization of the state, deregulation, individual 
liberty, free market and free trade (Harvey, 2007). The sole purpose of the state is to establish an institutional framework that permits the latter characteristics (Harvey, 2005). For example, the state needs to set up a military, police and a legal structure, as well as proper functioning markets (Harvey, 2005). The state must also create markets in areas that may be nonexistent, such as education and health care (Harvey, 2005). However, the state must not exceed its role or participate in the markets, after they have been created (Harvey, 2005). The state does not obtain adequate knowledge to “...second-guess market signals (prices) and because powerful interest groups will inevitably distort and bias state interventions particularly in democracies for their own benefit (Harvey, 2005, p. 2)." Neoliberals also contend that most policy issues, such as "illegal" migration occur due to government failure (Burke, Mooers and Shields, 2000). In accordance with this rhetoric, a solution may be for the welfare state to shrink (Shields, 2004).

Accordingly, most of the economic activity that was once part of the public sphere, has now been privatized (Amin-Khan, 2015). As the state continues to downsize, citizens, families and non-profit agencies are being strained with new responsibilities (Shields, 2004). For example, the state has limited public funding for community agencies, which seek to provide assistance for newcomers when they arrive in Canada (Shields, 2004). Neoliberals contend that by downsizing state responsibility, it provides individuals with greater freedoms (Shields, 2004). It also provides individuals with greater responsibilities to succeed, as well as to take care of their and their families' well-being (Shields, 2004). Thus, neoliberalism has put an onus on highly educated, highly-skilled, self-sufficient migrants who can contribute to the economy, as soon as they arrive in Canada (Arta-Koc, 2012; Bauder 2011; Gabriel, 2006).

Ideal immigrants are being pinned against those that are perceived as bad migrants (Bauder, 2001). A bad migrant might be one that could pose a threat to state resource or a person 
who entered the state via illegal avenues or surpassed his or her work permit (Bauder, 2011). People who may be illegalized beyond his or her choice, are perceived as underserving and undesired. They are not provided with a clear path to citizenship, in order to prevent them from draining state resources e.g. health, social assistance. Minimizing the use of state resources is key. Immigration is selective, and it is used as a tool to regulate who can come in and who has to stay out (Bauder \& Shields, 2015). It is imperative to be critical of these attitudes. If a person crosses a border "illegally," it does not entail that he or she cannot contribute to society. On the contrary, these illegalized immigrants, are contributing through the fruits of their labour, and they even pay taxes. Similarly, prior to becoming illegalized, many temporary foreign workers are also contributing to society. Yet, they are perceived as incapable of contributing to society, as they are "lazy," lack skills and work ethic.

This summer, I travelled to Holbox Island (Isla Holbox). It is located on the north coast of the Yucatán Peninsula, México. As I arrived at the island, a young boy caught my attention. He was around six years old. At my amazement, he was building a beautiful and perfectly shaped table-- by himself. I called him a self-made carpenter. He was skilled. He had a strong work ethic. He certainly was not lazy. As I stood on the street, I witnessed how hard every person was working around me. Yet, migrants are generalized as underserving and incapable of contributing to society. The negative rhetoric may help to justify the restrictions that seek to keep undesirable migrants out. It may also help to mask the states role in generating illegalized immigrants. Instead of blaming the state, a negative rhetoric shifts blame on illegalized immigrants.

Historically, Canada used overt discriminatory and racist policies to keep people out. Now it uses the point system, in order to restrict the movement of undesirable migrants (Sharma, 2015). The point system is also used to guide the labour market and obtain immigrants who are 
self-sufficient and educated (Gabriel, 2006). From a macro-perspective, the point system may seem objective, but in reality, it fails to consider the notion of race, gender and "low-skills." The notion of skill is a social construction, which perpetrates the gendered and racial division of labour (Gabriel, 2006). The term skill is not objective, as it systematically undermines some skills, such as women's attribution to society. For example, social reproduction and domestic labour are usually carried out by women in the home. The point system fails to provide women with formal points for their unpaid work experience, which is another problematic issue with neo-liberal driven values (Gabriel, 2006). The point system solely attributes points based on formal education, training, occupational experience and language proficiency (Gabriel, 2006). The point system fails to consider that women may not have the same opportunities as men (Gabriel, 2006). This may prevent them from attaining higher education and language training (Gabriel, 2006). In fact, a different level of educational opportunity is the second factor that will determine whether a woman will attain enough points to enter Canada on her own merit, instead of depending on family reunification (Gabriel, 2006). Women are disproportionately represented in the family class category, instead of applying as independents (Gabriel, 2006). As a result, they are at greater risk of becoming illegalized, as a result of a relationship breakdown (Goldring, Berinstein \& Bernhard, 2009).

Further, the point system assumes that immigrants bring value through education, as they will become self-sufficient and successful upon arrival to Canada, but the reality is that foreign credentials are rarely recognized (Girard \& Bauder, 2007). That is, many high-skilled immigrants enter Canada through the point system, yet they are unable to find jobs as they do not possess the Canadian Work Experience (Gabriel, 2006). Foreign educational credentials and 
work experience are often devalued or unrecognized, thus it prevents many immigrants from attaining jobs in their respective occupations (Girard \& Bauder, 2007).

Neoliberalism has also put an onus on generating short-term economic benefits (ArtaKoc, 2012), which is visible in Canada's Temporary Foreign Workers Program (TFWP). The program was created in order to fill temporary labour shortages (Siemiatycki, 2015). Workers can obtain work visas from 2 to 4 years (Siemiatycki, 2015). The program consists of live-in caregivers, low-skilled occupants and high-skilled occupations (Hannan, 2013). Canada has witnessed an increase in the entry of temporary foreign workers (Marsden, 2011), notably due to the expansion of the program, which now includes low-skilled workers (Foster, 2012). Now Canada may witness an increase of illegalized immigrant, due to recent changes to the program. In 2011 the federal government implemented a new regulation, which prevents "low-skilled" temporary workers from working in Canada for more than four cumulative years (Government of Canada, 2015). It also prevents them from re-applying for a work visa for an additional four years (Government of Canada, 2015). The new regulation may create more illegalized immigrants, as it may force them underground and into precarious work.

In the past, foreign workers were promised political membership to the state (Austin \& Bauder, 2010). However, migrants are no longer provided with a clear pathway to citizenship (Austin \& Bauder, 2010). The TFWP is undermining citizenship in Canada, as low-skilled temporary workers do not have a clear pathway to citizenship (Root, Gates-Gasse, Shields \& Bauder, 2014; Leach, 2013; Social Planning Toronto, 2013, Austin \& Bauder, 2010; Arta-Koc, 1999). Neo-liberal values are breaking the historical patterns of immigration in terms of migration, citizenship and nation-building (Arta-Koc, 1999; Root, Gates-Gasse, Shields \& Bauder, 2014). Canadian values have shifted from a more all-encompassing nation-building 
state, towards a more selective state, which seeks to address labour market needs with the TFWP and "low skilled" labour (Root, Gates-Gasse, Shields \& Bauder, 2014).

Canada has a preference for capitalizing on short-term temporary labour, over long-term immigration. The workers are also temporary in nature, but it is a permanent solution. In other words, temporary workers do not have full membership to the political community. Workers have a visa restriction and no voting rights. The pathway to citizenship is also restricted (Root, Gates-Gasse, Shields \& Bauder, 2014; Leach, 2013; Social Planning Toronto, 2013; Austin \& Bauder, 2010; Arta-Koc, 1999). It is a permanent solution in the sense that temporary workers serve to address social issues, notably Canada's low-birth rates and aging population (Arat-Koc, 1999).

Dobrowolsky (2012) asserts nine reasons that stipulate the shift from immigration policy towards seeking economic profit, as well as focusing on the illegalized immigrant's phenomenon:

(a) attract highly skilled immigrants; (b) expand low wage, temporary foreign worker programs; (c) diversify immigration "entry doors" and make some more flexible; (d) cut admission and settlement costs; (e) encourage settlement in less well-populated areas; (f) tighten border and crack down on undocumented migrants; (g) "change citizenship rules to reduce risks of undesired costs and unrealized benefits to the state," and (h) "sell immigration to the Canadian public... through a policy rhetoric that emphasized the hoped-for benefits of immigration while downplaying risks and disappointing outcomes." (p. 197-198).

Immigration policy should not be treated as a vehicle to generate profit. Organizations have benefited from employing illegalized immigrants, in part, due to the fact that their vulnerable status precludes them from making demands for equitable pay (Hannan, 2013). Overall, Dobrowlsky's reasons demonstrate that migrants are perceived as sole profit. However, it is barely concerned with ensuring that the migrants generate profit of their own or that they receive 
equitable employment. Illegalized immigrants make up a key component of low-wage and vulnerable workers (Standing, 2011).

Illegalized workers are a central component of the contemporary labour market, and it is also essential for neoliberal capitalism (Hannan, 2015; Hannan, Bauder \& Shields, 2016). In other words, society is dependent on illegalized immigrants, but on the other hand, they are under-acknowledged for their contribution to the economy. According to Sassen (2006), global cities have put an onus on high-prices and services and products by a very narrow high-income population. On the other hand, however, it has put an onus on low-cost services and products, as a result of a rapidly low-income population (Sassen, 2006). The rise of an information economy means that the capitalists can reduce costs in terms of labour and provide a flexible and disposable pool of human capital (Sassen, 2006).

\section{PART II}

The following literature review is an overview of scholarship regarding illegalized immigrants. The literature review includes both primary and secondary studies, and grey literature. The main electronic databases that were used to locate articles are: JSTOR, Routledge Taylor and Francis Group, ProQuest Research Library and Google Scholar. Further, reference lists were also used to locate additional articles, and websites and google were used to locate relevant grey literature. After gathering the literature, the following themes developed and will be discussed in detail: 1) a lack of exit control; 2) operational definitions; 3) the process of illegalization; 4) working conditions for illegalized workers; and 5) sanctions for employers. The five themes are important, as they provide relevant background in order to understand this phenomenon. 
The literature review begins with information regarding the lack of exit controls in Canada, in order to understand why it is difficult to estimate the number of illegalized immigrants. It will then discuss the negative language that is used to justify and continue to exclude "underserving" illegalized immigrants. It then discusses the process of illegalization. More especially, it discusses different avenues that can render a person "illegal," such as temporary foreign workers surpassing their work visa. After they become illegalized, they may be forced into the underground labour economy, which will render them more susceptible to exploitation by employers. Thus, the third theme that emerged is working conditions for illegalized workers. Lastly, legal sanctions against employers will be reviewed. Sanctions are supposed to "protect" illegalized workers and deter employers from hiring them. However, as De Genova (2013) contends, strict law enforcement is merely for show. In other words, it disguises the state's role in generating illegalized immigrants, which creates an environment that allows illegalized immigrants to be exploited.

\section{II.1 A Lack of Exit Controls}

There are no accurate figures regarding the number of illegalized immigrants residing in Canada, but most estimates range from 80,000 to 500,00 (Hannan, 2015; Goldring, Berinstein \& Bernhard, 2009). This is, in part, due to the fact the Canada does not have exist controls (Government of Canada, 2016). This means that it does not track who leaves the country. This makes it impossible to know how many migrants remain in the country, after the expiration of their student, visitor or work permits (Brillinger, 2015; Khandor et al., 2004). Goldring, Berinstein and Bernhard (2009) suggest that the range makes it difficult to define the population. It is difficult to understand how to address this phenomenon, if there is a lack of knowledge as to how many people are being affected. 
However, as a way to demonstrate border control, Canada may be implementing an exit control. Currently, information is collected regarding when and where a traveler enters Canada, but it does not collect information regarding when and where travelers leave (Government of Canada, 2016b). Canada and the U.S. share entry information on third-country nationals, as well as permanent residents of both countries (Government of Canada, 2016b). The information that is shared between both countries servers as an exit control, as collecting information regarding entry into one country acts as an exit record for the other country (Government of Canada, 2016b). However, the current system does not collect information regarding citizens of either country, and it does not track people leaving by air (Government of Canada, 2016b). According to the government of Canada, an exit control will "strengthen the security and integrity" of the border (Government of Canada, 2016b).

An exit control will be able to keep track of every person that leaves the country, including visitors, temporary workers and international students. Although this initiative will help to provide a better picture as to how many people surpass their stay in Canada, it may not necessary succeed in removing those people or deter them from remaining in Canada. Ultimately, it may not succeed in reducing the number of illegalized immigrants. While the TFWP continues to expand, it continues to have tighter rules and paths to permanent residency and citizenship continue to shrink. Illegalized workers that fall under the crack and remain in Canada, will continue to be exploited. State policies that seek cheap labour is putting these migrants in these positions, and this new initiative will merely serve as propaganda to demonstrate to the public that the state is attempting to control "the problem." The problem is not the illegalized immigrants. The problem is the state that is creating an environment that is 
producing illegalized immigrants. This environment also allows illegalized immigrants to be exploited for cheap labour.

\section{II.2. Operational Definitions}

First and foremost, it is important to discuss terminology that will be used through this paper. Different words carry different connotations, and many critics use terminology that is often dehumanizing and incorrect. Being cautions of the terms that are used to refer to illegalized immigrants is important, as it shapes public opinion regarding immigration policy (HaqueHausrath, 2016). Further, in accordance with De Genova (2002) and Goldring, Berinstein \& Bernhard (2009), the terms "illegal," "legal" and "illegality" will be enclosed with quotations. The purpose of the quotations is to question the "social, administrative, legal and political construction of the category as applied to migrants (Goldring, Berinstein \& Bernhard, 2009, p.239)." Throughout this paper the terms "low-skilled" and "high skilled" will also be enclosed with quotations. The term skill fails to consider the notion of race and gender, and it perpetrates the gendered and racial division of labour (Gabriel, 2006).

Numerous terms throughout North America and Europe are used, such as "illegal," "unauthorized", "alien," "wet-back" (Goldring, Berinstein \& Bernhard, 2009), "irregular," "extra legal" "irregular" and "clandestine" (De Genova, 2002). Most of these terms are used to describe migrants who cross a border without authorization (Goldring, Berinstein \& Bernhard, 2009). In the United States, advocates use the undocumented vs. documented binary, as it reflects the phenomenon at the Mexico-US border (Workers Defense Project, 2013; Goldring, Berinstein \& Bernhard, 2009; De Genova, 2002). Most migrants transcend the border without "legal" documentation, notably Mexican nationals. 
In Canada, contrary to common misconceptions, transcending a border via "illegal" means is not the most common avenue of illegalization (Bauder, 2013; Goldring, Berinstein \& Bernhard, 2009). That is, at one point in time, illegalized migrants had authorizing documents. Consequently, the undocumented vs. documented binary does not accurately reflect the situation in Canada. Most migrants arrive via legal avenues (Bauder \& Shields, 2015), such as the TFWP. However, illegalized workers surpass their work permit, as they cannot navigate a pathway to citizenship. In other words, the federal immigration policies generate a class of precarious migrants, whom are marked with a non-existent pathway to citizenship and lack secure basic rights and entitlements (Goldring, Berinstein \& Bernhard, 2009). Consequently, other terms have been adopted in Canada, which seek to undermine the negative discourse and depict the bureaucratic realties that are rending people "illegal," such as non-status (Nyers, 2010), precarious status (Goldring,Berinstein \& Bernhard, 2009) and illegalized immigrants (Bauder, 2013). The latter will be used throughout this paper.

The term "illegalized immigrants" creates a discourse that goes beyond the illegal vs. legal binary and the documented vs. undocumented binary (Bauder, 2013; Goldring, Berinstein \& Bernhard, 2009). It blames the immigration policies that renders migrants "illegal" (Bauder, 2013; Dauverge, 2008), shifting the blame away from the migrant (Bauder, 2013). Being "illegal" is not always a choice. The central argument of this paper is that neoliberal policies are rendering migrants "illegal." Hence migrants are being illegalized by immigration policy, and it may force migrants to go underground and into precarious work.

According to Goldring, Berinstein and Bernhard (2009), "precarious migratory status, like citizenship, is multi-dimensional and constructed by specific state policies... there may be multiple pathways to precarious status (Goldring, Berinstein and Bernhard, 2009, p. 240)." There 
are multiple pathways to illegalization, as people can surpass their student, work or visitor visa, but they can also become illegalized due to a family sponsorship breakdown or a failed refugee claim (Bauder \& Shields, 2015; Hannan, 2013; Goldring, Beirstein \& Bernhard, 2007). They also suggest that a person's legal status cannot be determined in a "black-and-white" manner, as people are continually fluctuating between statuses. As a result of migrants shifting through different classes of statuses, migrants also shift through different levels and/or access to services (Nyers, 2010; Bernhard, Goldring, Young, Berinstein \& Wilson, 2009). This, in turn, means that a person can be pushed into a position whereby he or she does not obtain any political membership or privileges (Nyers, 2010). As entitlements are inherently interconnected with a person's immigration status, during a period of time when a person is fluctuating from a "legal" to an "illegal" status, the person will lose access to essential services (Berinstein, Nyers, Wrights \& Zeheri, 2006). Further, the status of a migrant can also have regular and irregular characteristics at the same time (Duvell, 2011). For example, a migrant may have a residence status, but he or she may be working without a work permit (Duvell, 2011).

Critics typically use the term "illegal." The term is pejorative and inaccurate (Sharma, 2015). Illegality cannot apply to human beings (Sharma, 2015). By referring to a human being as "illegal," one suggests the person rather than their actions are illegal (Sharma, 2015). However, only actions that people commit can be deemed illegal (Sharma, 2015; Nyers, 2010). The term "illegal" is also dehumanizing, and it contributes to a negative discourse (Bauder, 2013). It carries a myriad of negative implications (Sharma, 2015; Bauder, 2013; Nyers, 2010), such as unwanted, non-belonging and racialized outlaws (Bauder, 2013). Society may assume that the term implies that an "illegal" person has no civil or workplace rights, but in fact every person has rights, irrespective of his or her immigration status (Workers Defense Project, 2013). 
Lastly, a phrase that will be used is "the fruits of their labour," which will be defined as the exploitation of workers for cheap and disposable labour. Employers fail to provide employees with adequate remuneration and protection, yet on the other hand, they benefit from their labour. Though this term has not been used in this context, it stipulates the realities that are occurring in the 'underground' market. The following section will discuss the process of illegalization.

\section{3 The Process of Illegalization}

The illegalization process is a direct by-product of rigorous immigration policies. In other words, the institutional and political process creates a binary categorization of migrants, which lacks secure basic rights and entitlements (Goldring, Berinstein \& Bernhard, 2009). In fact, most illegalized migrants enter through legal channels, such as family sponsorship, refugee claims, and student, work or visitor visas, but they often surpass the authorization expiration date (Bauder \& Shields, 2015; Hannan, 2013; Goldring, Beirstein \& Bernhard, 2007). A myriad of reasons may influence a person to stay, which may lead to the illegalization of a person. Although some migrants attempt to seek permanent residency, it could take months or years (Social Planning Toronto, 2013; Brillinger, 2015). It also requires a considerable amount of resources for migrants, while also navigating a robust immigrant system (Social Planning Toronto, 2013; Brillinger, 2015).

People can become illegalized in various ways (Bauder, 2014). A person can enter a country "legally" such as through the TFWP and then surpassing his or her visa. However, people also enter "illegally" such as crossing the border via illegal avenues. For example, Mexican nationals crossing the Mexico-U.S. border (Bauder \& Shields, 2015). Some migrants 
even pay smugglers between 20,000 to 50,000 per person (Criminal Intelligence Service Canada, 2005). However, entering Canada through illegal means is less unlikely, due to Canada's geography, border landscape and immigration policy (Goldring, Berinstein \& Bernhard, 2009). Most illegalized migrants enter through legal channels, such as family sponsorship (Bauder \& Shields, 2015; Hannan, 2013; Goldring, Beirstein \& Bernhard, 2007).

There are gender-dimensions in the illegalization process. Canadian and permanent residents can sponsor close family member and/or close relatives (Goldring, Berinstein \& Bernhard, 2009). Spouses and partners can reside in Canada, while they wait for the decision. However, if the relationship breaks down, the spouse or partner may be left without a status (Goldring, Berinstein \& Bernhard, 2009). This typically affects women more than men, as the point system is inherently gender neutral. Women represent $59 \%$ of family reunification applications, compared to $4 \%$ of males (Arat-Koc, 1999). Once women are illegalized, their well-being along with the well-being of their "illegal" and/or "illegal" children are impacted (Bernhard, Goldring, Young, Berinstein \& Wilson, 2009). Illegalizes women also face a myriad of issues, such as poverty, unemployment, housing instability and exploitation (Paradis, Novac, Sarty \& Hulchanski, 2008), and they cannot attain income assistance (Bernhard, Goldring, Young, Berinstein \& Wilson, 2009).

Illegalized women can become dependent on their partners or husbands notably due to the disproportionate amount of women being sponsored, in conjunction with sponsorships breakdowns (Bernhard, Goldring, Young, Berinstein \& Wilson, 2009). Illegalized women are also at greater risk of experiencing domestic violence (Berinstein, Nyers, Wrights \& Zeheri, 2006). According to Berinstein, Nyers, Wrights \& Zeheri (2016), illegalized women are more vulnerable to domestic violence, due to the fear that abusers hold over them. The abuser, often a 
partner or spouse, may threatened to report the non-status women to the police, if they do not abide (Berinstein, Nyers, Wrights \& Zeheri, 2006).

Secondly, a failed refugee claimant can also become illegalized, if he or she remains in the country after the claim is rejected (Nyers, 2010). As Canada signed the United Nations High Commission for Refugees, it has an obligation to provide asylum to persons with a "wellfounded fear of being persecuted for reasons of race, religion, nationality, membership in a particularly group or political opinion (Worsten, 2012)." The definition has a narrow range, which ultimately prevents the convention from applying to every type of refugee (Buchanan, 2010). For example, the definition fails to encompass gender-dimensions. Failing to consider these dimensions means that women that need protection may be denied refugee claims and may be illegalized.

The application process in Canada is also stringent and lengthy (Goldring, Berinstein \& Bernhard, 2009; De Genova, 2013). It is embedded with suspicion, thus it has a high rejection rate, as it it cautious of "bogus" refugee claims (De Genova, 2013). These initial asylum seekers are scrutinized as "illegal" "unwanted" "underserving" and "undesirable" (De Genova, 2013). These notions justify the stringent refugee system, which then creates a pool of illegalized asylum seekers. If a claimant does not fulfill the criteria for an asylum application, the claim can be rejected (Goldring, Berinstein \& Bernhard, 2009). Canada has implemented many legal barriers to deter or prevent refugee claims, such as the visa implementation, the Designated Country of Origin List, establishing a category for "irregular arrivals" and a narrow definition of a Refugee (Siemiatycki, 2015). It is possible that many failed refugee claimants will find other means to remain in Canada. In fact, from 2012-2013 approximately 2,000 failed refugee claimants remained in Canada (Agency, 2012). 
The illegalization process is a direct by-product of rigorous immigration policies. The process strips illegalized immigrants of secure basic rights and entitlements. Although many contribute to the economy through the fruits of their labour, the binary classification of a person prevents illegalized immigrants from having the same protection and legal rights as Canadian citizens and permanent residents (Bacon, 2008). In addition, the classification of a person determines their wage, working standards, protections, access to social services, such as health care and welfare, or even the ability to change employer (Sharma, 2015).

The following section will discuss the Sanctuary City movement in Toronto. It is a space where illegalized immigrants can access municipal services. It is a possible but limited solution, as labour and employment rights are under provincial jurisdiction. Illegalized immigrants gravitate towards cities, while these spaces are embodied by exploitation (Bauder, 2015). Paradoxically, the movements to fight against exploitation and to fight for rights are also born in cities (Bauder, 2015). The following section will discuss working conditions for illegalized workers, after they become by-products of strict neo-liberal policies.

\section{II.4 Working Conditions for Illegalized Workers}

The following quotes were voiced by illegalized immigrants. The quotes are important to incorporate, as they depict the realities that illegalized immigrants encounter on a day-to-daybasis. Most terminology regarding illegalized immigrants is negative and dehumanizing. Incorporating these quotes in this MRP is not going to change public perception of "illegal" immigrants, but it can begin to create a positive rhetoric regarding illegalized immigrants. Instead of viewing them as "illegal" or "aliens" that do not belong or that are not good enough, their stories will depict them as human beings. Being "illegal" is not necessarily their choice, as the bureaucratic forces is pushing them through the cracks. Without a political membership, it 
means that they do not have a right to vote, and their voices may not be heard by political members to implement real change regarding their labour exploitation. In order to start generating a positive rhetoric, their experiences regarding labour exploitation should be central to this issue.

A lot of employers are delighted to hear that you have no papers, because they can overwork you and exploit you (Nyers, 2010, p.132).

It really drains you that you have to work 12-hour shifts for very little money. I used to be young. No I feel so old (Nyers, 2010, p.132).

For the medical, I have to be my own doctor practically. You know, because it's very expensive (Berinstein, et al., 2006).

I am a lawyer, but if you don't have status then you are nobody (Nyers, 2010, p.132).

They know we are weak. We are different in all ways. Even with regard to hours worked. We do 14-15 hours every day with less pay ... it is exploitation. We are weak ... [the employer] ... is getting cheap labour, saves him taking another person on and save him money (Bloch, Kumarappan \& Mckay, 2014, p. 141).

And if there is still work to do [available], it does not matter because you know that you may have to move to another city or another job at the moment when you least expect it. You do not have a sense of security around other people. You do not have that. You almost have to walk around without saying a word all the time. You can't comment on anything (Bernhard, Goldring, Young, Berinstein \& Wilson, 2009, p.107).

It remains the case that, without full protection from labour and employment laws, illegalized immigrants are highly susceptible to abuse and exploitation. ${ }^{2}$ Illegalized immigrants

\footnotetext{
${ }^{2}$ For illegalized immigrants, driving a car, going to school or jaywalking can put him or her at risk of deportation (Nyers, 2010). Illegalized immigrants are even too scared to call 911, if they require assistance (Nyers, 2010). This is due to the fact that some illegalized women have been incarcerated for attempting to call the police for assistance (Nyers, 2010). As a result, women become vulnerable to domestic violence, while at the same time, they become dependent on the abuser (Bernhard, Goldring, Young, Berinstein \& Wilson, 2009).
} 
are less likely than legal migrants to be employed in higher paying occupations (Hannan, 2015). They typically work in low-skilled jobs, and the jobs are part-time or seasonal, which renders them vulnerable to abuse (Hannan, Bauder \& Shields, 2016). The types of jobs that they usually obtain are in the construction sector, hospitality, food processing, manufacturing industries and in domestics, such as nannies, gardeners, caregivers, cooks and cleaners (Bauder, 2014; Walia, 2010; Hanson 2009). All of these jobs have four characteristics in common: they are dangerous, precarious, pay low wages and undesirable by the Canadian population (Hannan, Bauder \& Shields, 2016). However, illegalized workers do not have legal rights to obtain a work permit or a social insurance number, thus these exploitable jobs continue to attract a large pool of workers (Walia, 2010).

Illegalized immigrants are vulnerable to abuse by employers, due to the power imbalance that employers hold over them (Hannan, 2013). Employers can keep illegalized immigrants in unhealthy and unsafe conditions, as illegalized immigrants are scared to assert their rights (Workers' Action Centre, 2011). Illegalized immigrants are typically threatened with being reported to officials, which could lead to deportation (Workers' Action Centre, 2011). For example, in Seattle, an employer threatened workers that were seeking to recover unpaid wages (Cho \& Smith, 2013). Consequently, the employer contacted the Immigration and Customs Enforcement (ICE) and the worker was arrested (Cho \& Smith, 2013). An injured worker, in New York, was arrested on false criminal charges, as the employer called ICE (Cho \& Smith, 2013). The arrest happened prior to a hearing regarding labour claims (Cho \& Smith, 2013). The power imbalance makes it difficult for illegalized immigrants to make demands (Hannan, 2013). Consequently, they are susceptible to unfair and dangerous working conditions, and they are not eligible for worker's compensation if he or she is injured at work (Khandor et 
al., 2004). As a result of a work place injury, illegalized workers are unlikely to seek medical attention (Berinstein, et al., 2006). They are paid below federal and provincial minimum wage, work long hours (with no overtime pay), live in crowded accommodations, work in unsafe conditions, and they have limited resources in the event of abuse at work (Hannan 2013;

Goldring, Berinstein \& Bernhard, 2009).

Many illegalized immigrants work in hard labour jobs with inadequate health and safety conditions, and so are more likely to get injured at work (Workers' Action Centre, 2011; Khandor et al., 2004). Nevertheless, they are not eligible for worker's compensation if injured at work (Walia, 2016; Hannan \& Bauder, 2015; Khandor et al., 2004). In addition, as a result of a workplace injury, illegalized workers are unlikely to seek medical attention (Berinstein, et al., 2006). For instance, the construction sector is known for high workplace injuries, yet they still do not attain adequate medical care (Berinstein, et al., 2006). Illegalized workers will avoid medical attention, as they fear that the hospital staff may report them to immigration authorities, and they lack sufficient funds to pay for the hospital bills (Walia, 2016; Berinstein, et al., 2006; Khandor et al., 2004). According to a quantitative study in the Chicago metro area, only $25 \%$ of illegalized immigrants are covered by health insurance (Mehta, Theodore, Mora \& Wade, 2002). Although illegalized immigrants rely on networks to help them in case of an emergency, certain situations may require professional care (Berinstein, et al., 2006). ${ }^{3}$

Employers prefer to hire illegalized immigrants, as they are unable to unionize, due to a lack of full-legal status (Hannan, Bauder \& Shields, 2016; Hannan \& Bauder, 2015). In the United States, a group of illegalized immigrants attempted to participate in unionizing events, in

\footnotetext{
${ }^{3}$ The exploitation, vulnerability and precarious status of illegalized immigrants also has other health impacts. Many illegalized immigrants have reported depression and another worker reported that he has a plan to commit suicide (Workers' Action Plan, 2011).
} 
order to claim unpaid wages and report labour violations (Hannan, Bauder \& Shields, 2016). The scenario did not end well for the workers, as the employer reported the illegalized immigrant to the authorities (Hannan, Bauder \& Shields, 2015). This demonstrates the power that employers hold over illegalized immigrants (Bauder, 2014).

Employers benefit from employing illegalized immigrants, as they are also unable to make demands for equal and fair wages (Hannan, 2013). Quantitative studies have concluded varying hourly wages for illegalized immigrants. Mehta, Theodore, Mora \& Wade (2002), examined a survey of 1,653 "legal" and "illegal" immigrants. The quantitative study found that illegalized men earn 22 percent less than "legal" males, and women earn 3 percent less than "legal" females (Mehta, Theodore, Mora \& Wade, 2002). In addition to lower wage rates, illegalized immigrants are more likely to experience situation where they do not receive their pay checks and/or overtime pay. In Los Angeles, a quantitative study found that almost 76 percent of illegalized workers did not receive remuneration for their work (Milkman et al., 2010). The study also found that 85 percent did not receive overtime pay (Milkman et al., 2010).

There are other factors that will affect an illegalized worker's wage, such as gender, nonEnglish fluency and race (Hannan, 2015). That is, a racialized illegalized woman will be compensated less for her labour, compared to an illegalized man. Another factor that will affect wages is having networks, including friends and relatives with migratory experience (Aguilera \& Massey, 2003). Note that the latter factor will typically result in a higher wage (Aguilera \& Massey, 2003).

Further, as the employer pays the illegalized work in cash, the employer avoids paying EI (Workers' Action Centre, 2011). According to Hannan (2013), all levels of government ought to unite, in order to implement policies that are inclusionary in nature for illegalized immigrants. 
They should be treated as equal members of the community, by providing them with equitable access to social welfare at federal state/provincial as well as municipal levels (Hannan, 2013). In addition, all the levels of government should create policy framework that requires employers to provide equitable wages to illegalized worker and hold them accountable to do so (Hannan, 2013). Whether this will have real results, is indicative of further study. The reality is that illegalized workers are "super-exploited" (Heyman, 1998). Paradoxically, they are more scrutinized under the law, compared to employers that are doing the hiring (Heyman, 1998). Illegalized workers are the by product of immigration policy, and the labor effects tend to favor capitalists (Heyman, 1998). The following section will discuss sanctions for employers that hire illegalized workers.

\section{II.5 Sanctions for Employers}

This section will discuss the method that Canada uses, in order to control the 'underground' economy. In accordance with section 124 (1) of the Immigration and Refugee Protection Act, every person commits an offence if he or she employs an unauthorized person (Government of Canada, 2016a). Failing to "exercise due diligence," in order to determine if the worker is authorized is also an offence (Government of Canada, 2016a). In accordance with section 125 , if a person is found guilty on indictment, he or she can face a fine of up to $\$ 50,000$ and/ or up to two years in prison (Government of Canada, 2016a). If a person is found guilty on a summary conviction, the person can face up to $\$ 10,000$ in fines and/or up to 6 months in prison (Government of Canada, 2016a). Although employers knowingly hire, benefit and exploit illegalized workers, they are rarely charged (Barrett, 2013). They are typically only charged if they engage in other rigorous misconduct, such as human trafficking (Barrett, 2013). 
In 2010, three men were arrested at the Shell station, as they did not have a work permit (Turner, 2012). The illegalize workers arrived to Canada via the TFWP three years earlier (Turner, 2012). As they were laid off and their work permits were coming to a near-end, the illegalized men paid a recruiter to find them jobs at a gas station (Turner, 2012). The men testified at the immigration hearing that their employer told them to begin working, prior to completing proper documentation (Turner, 2012). Note that a labour market opinion must be completed before applying for a work permit for foreign workers (Turner, 2012). Nevertheless, the men were deported and the company received a $\$ 12,000$ fine (Turner, 2012). Although this case may seem as a "success," it is important to question whether a fine is going to deter employers from hiring and exploiting illegalized workers or whether the benefit of hiring them outweighs the consequences. A fine is also not going to reduce the number of illegalized workers in Canada. Illegalized workers do not typically come to Canada. Visitors, students, temporary workers and spouses come to Canada "legally" and then the system illegalized them. Consequently, what is the purpose of employer sanctions?

According to Bloch, Kumarappan and Mckay 2014, sanctions merely serve as border control. However, sanctions actually worsen the vulnerability and exploitability of illegalized immigrants (Bloch, Kumarappan and Mckay, 2014). Studies have shown that not only do sanctions lead to further exploitability, but illegalized immigrants become less likely to report any harms (Gordon, 2006). Sanctions cannot deter illegalized workers, as migrants and employers adopt strategies to be able to continue to work and hire workers under the radar (Bloch, Kumarappan \& Mckay, 2014). It is then important to question why the government continues to focus on sanctions and why it is using it as a border patrol strategy. If sanctions actually worsen the vulnerability and they do not reduce the number of illegalized immigrants, 
then the state should focus on ensuring labour and employment rights for illegalized immigrants. Nevertheless, it may continue to apply sanctions against employers who hire illegalized workers, in order to demonstrate that it is attempting to control the "illegal" immigration issue. It cannot control it, however. It is creating the problem.

\section{PART III}

Part III of this MRP will first discuss the TFWP. The program was created in order to address temporary labour shortages (Siemiatycki, 2015), but it is becoming a permanent solution, as the program continues to grow and permanent residency continues to shrink. Temporary foreign workers have limited pathways to apply for permanent residency and recent changes to the program (influenced by neo-liberalism) will increase the number of illegalized immigrants. The strict rules are rendering the temporary foreign workers "illegal," as some workers will remain in Canada once their work visa expires. They will then be forced into the underground labour economy and be vulnerable to more exploitation. The following section will discuss the Sanctuary City movement in Toronto. The movement challenged state laws that serve to distinguish between citizens and non-citizens (Nyers, 2010). A Sanctuary City provides illegalized immigrants with access to municipal services (Bauder, 2015). However, a Sanctuary City movement is a "semi-solution," as it cannot enhance labour and employment rights for illegalized workers. This is due to the fact that labour and employment rights are under provincial jurisdiction. An improved solution may be to make Ontario a Sanctuary Province.

\section{III.1 The TFWP, the Illegalization of Temporary Workers and Semi-Solution}

The TFWP was created in order to address temporary labour shortages (Siemiatycki, 2015). The program consists of live-in caregivers "high skilled" (i.e. engineer) and "low skilled" occupations (i.e. agricultural labourer) (Siemiatycki, 2015; Hannan, 2013). Canada has 
witnessed an increase in the entry of temporary foreign workers (Marsden, 2011), notably due to the expansion of the program, which now includes low-skilled workers (Foster, 2012). The TFWP is not as simple as filling temporary labour shortages, however. The program seeks to fill certain types of jobs that other native-born do not want to fill. The low-skilled jobs can be described as the "three Ds" (Sharma, 2015). The jobs are dangerous, dirty and difficult (Sharma, 2015). Typically, migrant workers received low-wages (often below the official provincial and federal minimum wage), live in crowded accommodations, are denied access to public healthcare and employment insurance (note that they pay into these programs) and employers often seize passports (Walia, 2010).

Temporary workers are also tied to one employer (Pastor \& Alva, 2004). This means that if the employer no longer needs the worker, he or she must leave Canada (Pastor \& Alva, 2004). This makes the program highly restrictive in terms of labour mobility (Foster, 2012). This restriction also worsens a temporary foreign worker's vulnerability and exploitability, due to the power imbalance that employers hold (Walia, 2010). Employers know that if a temporary worker attempts to assert his or her rights, it could lead to the termination of his or her contract (Walia, 2010). As a result of the termination of the contract, it can also lead to deportation, as the employer is tied to one employer (Walia, 2010). This might make it difficult for temporary foreign workers to assert their rights, specifically as the program is a complaint driven system. Nevertheless, the program continues to expand and recent changes to the program has generated more illegalized immigrants.

In 2011, the Federal government implemented a new regulation, which prevents lowskilled temporary workers from working in Canada for more than four cumulative years, and it also prevents them from re-applying for a work visa for an additional four years (Government of 
Canada, 2015). It is also referred to as the "4-in-4-out" rule. Regardless of how long the temporary workers had been working in Canada, the time began to accumulate on April ${ }^{\text {st }}, 2011$ (Government of Canada, 2015). This means that the earliest the workers could reach the fouryear limit was April $1^{\text {st }}, 2015$ (Government of Canada, 2015). The regulation affected thousands of temporary foreign workers (CIS News, 2016). This is problematic in many respects. The new regulation may create more illegalized immigrants, as it may force them underground and into precarious work.

The purpose of the "4-in-4-out" rule is to ensure that foreign workers do not lose "ties" with their country of origin, as well as to "encourage" workers and employers to "explore" other avenues for permanent residency (Government of Canada, 2015). While temporary foreign workers can apply for permanent residency, most low-skilled foreign workers will not qualify. The program precludes the state from creating legal avenues for permanent residency (Root, Gates-Gasse, Shields \& Bauder, 2014; Leach, 2013). Although temporary foreign workers are imperative in order to fill labour-shortages, avenues for permanent residency are greatly limited. The following avenues are "available" to temporary foreign workers.

Temporary foreign workers have four avenues to apply for permanent residency: “(1) the Live-in Caregiver Program (LCP), (2) the Federal Skilled Program (FSWP), (3) the Canadian Experience Class (CEC); and (4) the Provincial/Territorial Nominee Program (Lenard \& Straehle, 2012, p.50)." These avenues are highly restricted. Although the LCP includes all "lowskilled" workers, it is actually just for live-in caregivers (Lenard \& Straehle, 2012). The FSWP and the CEC are for high-skilled temporary workers, thus low-skilled workers cannot enter through these avenues (Lenard \& Straehle, 2012). The avenues for temporary foreign workers can be characterized as restrictive and exclusionary, specifically for "low-skilled" workers. If 
temporary foreign workers do not have an avenue that may lead to permanent residency and citizenship, it may lead them underground. Thus, the state should create an avenue specifically for temporary foreign workers. It is clear that the current system is set up to ensure that temporary foreign workers solely come to Canada and work, while they do not have an opportunity to attain a community membership. The state knows that although they are "encouraged" to "explore" other options, these options are greatly limited. In addition, a person can indeed lose ties with their country of origin in four years. As a result, this rule will produce more illegalized immigrants, and the state will continue to benefit from this exploitable and vulnerable group of people.

Many migrants will continue working past the expiration of their work permit, as they will seek to continue to send remittances to their families or bring their families. Contributing the fruits of their labour for four years is an abundant of time. It is also enough time to build a new life, make a new home and see a future. Nevertheless, even if they are contributing to the economy and their communities, they must leave. If they remain in Canada, they become illegalized. The illegalization process of these workers is a direct by-product of the neoliberal rhetoric. This has and will continue to force workers underground, and as a result, force them into exploitive and precarious jobs. This is problematic in many respects, as they are solely being used for what they have to offer--cheap labour.

Temporary foreign workers and illegalized workers are a central component of the contemporary labour market, and it is also essential for neoliberal capitalism (Hannan, 2015; Hannan, Bauder \& Shields, 2016). Thus, the program has continued to grow. The program doubled from 102,932 (in 2003) to 213, 573 (in 2012). Below figure I demonstrates the increase of temporary foreign workers, since the program commenced. 
Figure I: Number of temporary residents in Canada by category, 1988-2012 (As cited in Solidarity City, 2013).

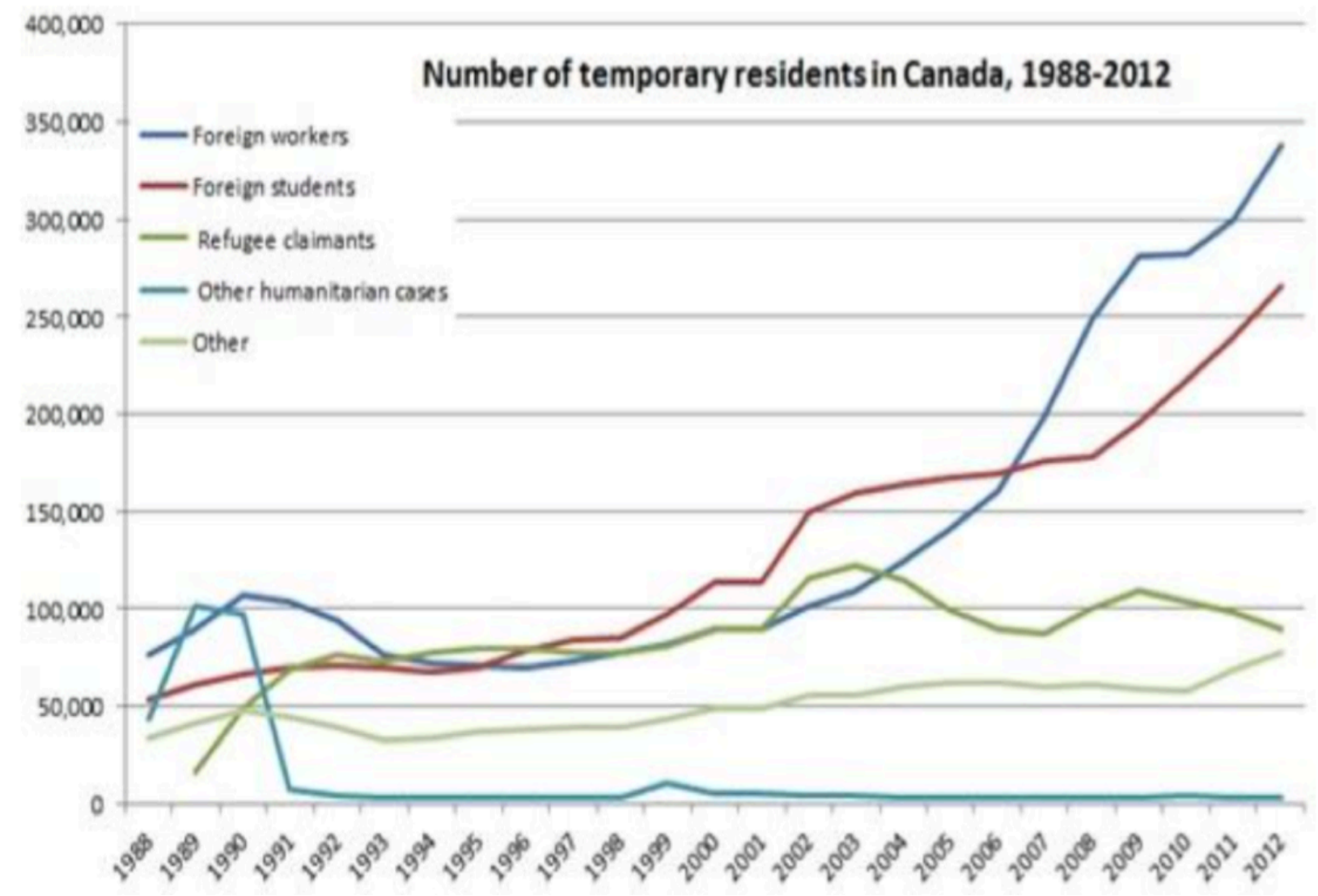

As shown in figure I, the TFWP program has drastically, and for the most part, steadily increased. The market is increasingly relying on temporary foreign workers (Root, Gates-Gasse, Shields \& Bauder, 2014). While the number of temporary foreign workers continues to increase, the number of permanent residents continues to decrease (Solidarity City, 2013). This is a reconstruction of the previous immigration system (Siemiatycki, 2015). In the past, migration was used to strengthen the economy, as well as for nation-building efforts (Siemiatycki, 2015). Migrants used to come to Canada with their families, but now they arrive alone (Siemiatycki, 2015). Since the 1980 s to the present, Canada has continued to emphasis "high skilled" based immigration (Hannan, 2015). Many temporary foreign workers are "low skilled," thus they are 
usually not eligible for permanent residency (Siemiatycki, 2015). This means that although they are suitable enough to participate in the labour market, temporary foreign workers are not suitable enough to be part of the political community (i.e. welfare, EI, vote).

Figure II: Permanent and Temporary (Non-Visitor Landing into Toronto) (Social Policy, Analysis \& Research, 2013).

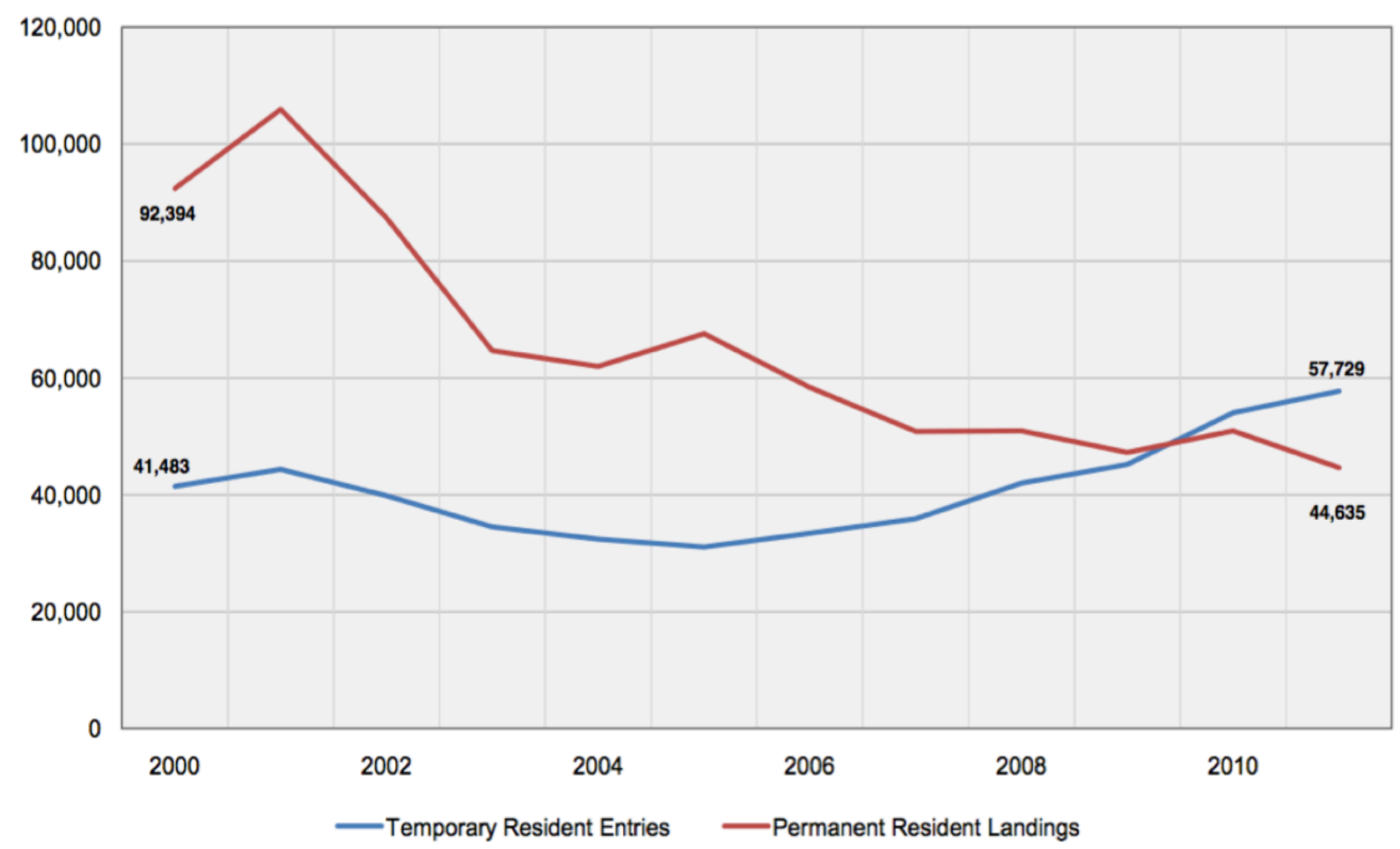

Note that these data are for landings/entries only and do not take into account where individuals move after entering the country.

Permanent resident data includes family class, economic immigrants, and refugees granted permanent resident status. Temporary entries include students, workers, and refugee claimants who have not yet been granted PR status, but does not include visitors or other temporary resident permit holders.

Source: Citizenship and Immigration Canada 2012 RDM Extracts

Figure II demonstrates the number of temporary residents landing in Toronto, compared to the number of permanent residents. There has been a clear decrease of permanent residents. 
Figure III: Temporary Resident Entries (Non-Visitors) by Location (2011) (Social Policy, Analysis \& Research, 2013).

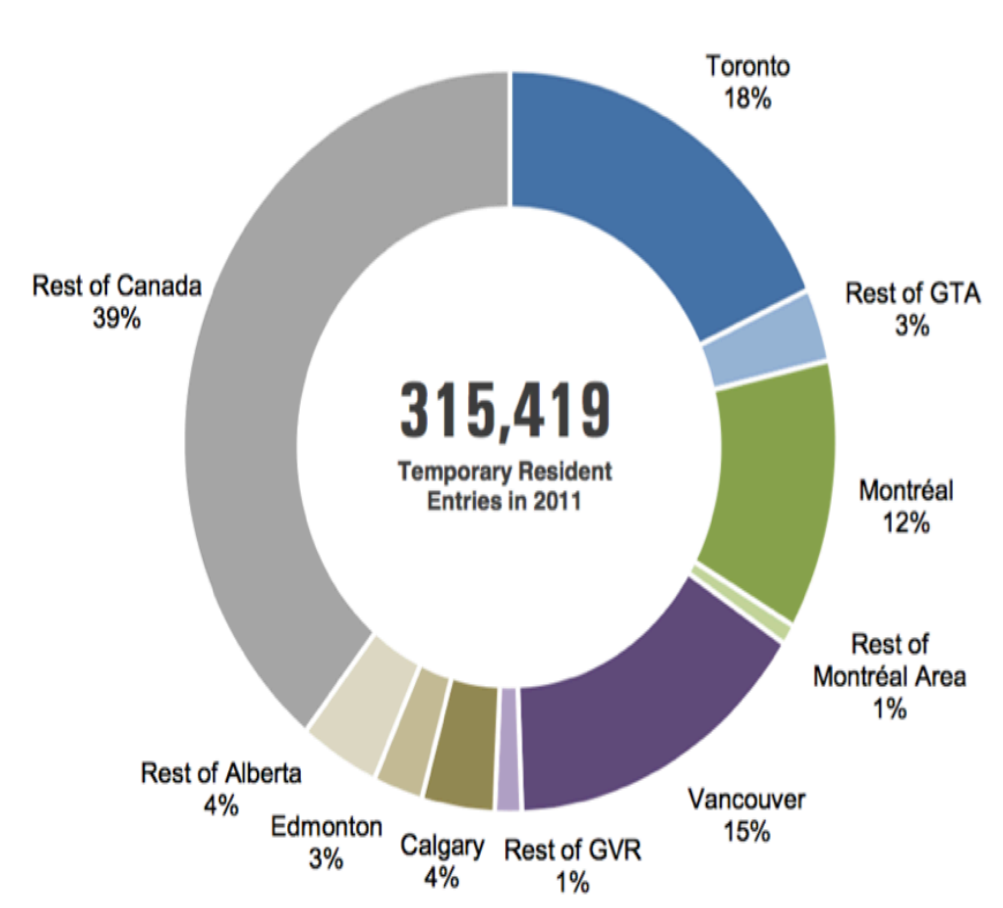

Temporary Entries in Toronto (2011)

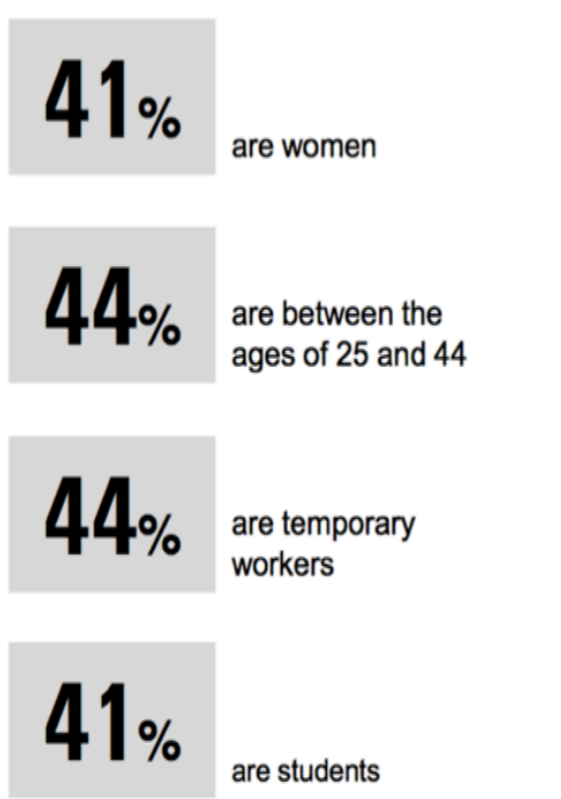

Temporary entries include students, workers, and refugee claimants who have not yet been granted PR status, but does not include visitors or other temporary resident permit holders. Source: Citizenship and Immigration Canada 2012 RDM Extracts

Figure III demonstrates where temporary residents are arriving. A large portion of temporary residents arrive in large cities. Similarly, the top three settlement destinations for illegalized immigrants are Toronto, Vancouver, and Montreal, with nearly 50\% of illegalized immigrants residing in Toronto (Khandor et al., 2004). Whether the entry of temporary residents in Toronto, correlates with the high number of illegalized immigrants residing in Toronto is indicative of further study. An important question is whether illegalized immigrants are more likely to surpass the expiration of their visa, if they enter through Toronto due to the resources/networking and Sanctuary City policies. Another important question is whether illegalized immigrants are more likely to move to Toronto, after the illegalized process and why. 
These are important questions in light of the new changes the program, which are expected to increase the number of illegalized immigrants in Canada. It is also important, in order to help understand whether illegalized immigrants feel that Sanctuary Cities can enhance their every-day lives.

With no clear path to citizenship, there is a twofold: 1) temporary foreign workers are being used and exploited for the fruits of their labour, as well as working under precarious and vulnerable positions; and 2) as some of these workers transition through the illegalization process, the latter characteristics will worsen, as they will have less protection from labour and employment rights, and employers will hold more power. When the worker becomes illegalized, they may become more susceptible to exploitation, as it become normalized. They may continue to believe that they have no labour and employment rights.

\section{Figure IV: Variables of Vulnerability and Exploitation}

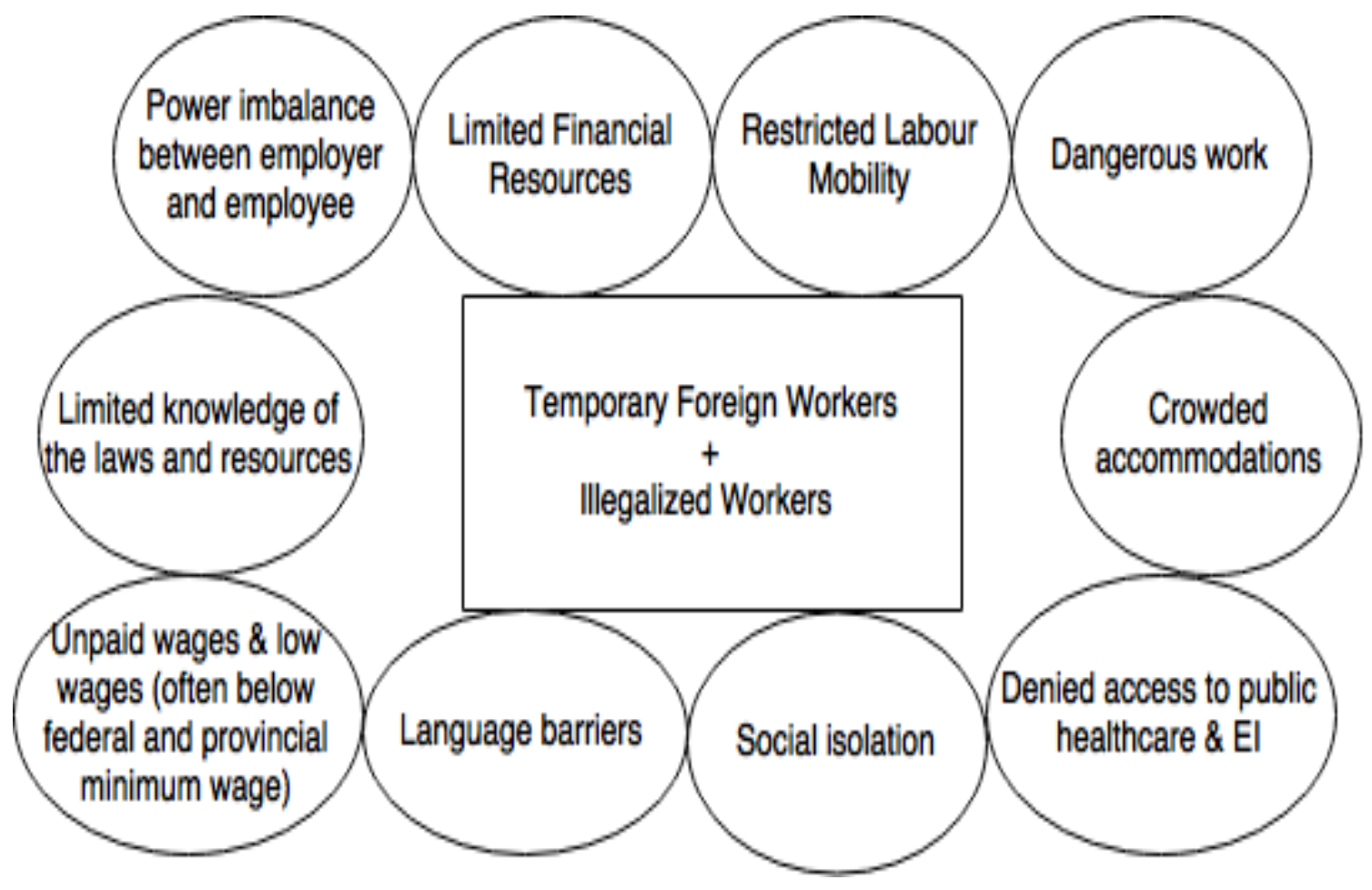


Figure IV demonstrates the variables of vulnerability and exploitation that temporary foreign workers may encounter. As some of these workers transition through the illegalization process, they are likely to encounter the same variables. The lack of status, however, may render them more vulnerable to exploitation. Temporary foreign workers have limited knowledge of laws and resources, thus illegalized immigrants may not know that he or she has labour and employment rights (i.e. the ESA). Many employers take advantage of "legal" and "illegal" workers for having limited knowledge of the law and being in a vulnerable position.

Temporary foreign workers are protected by basic employment protection, but it is highly difficult for these workers to navigate through the system and assert protection. These workers are also not allowed to access settlement services, they have language and cultural barriers and they rely on employer-provided orientation (as cited in Foster, 2012). This, may make it harder for them to navigate through the system, as they become illegalized. Although every worker, including illegalized workers, have basic labour and employment rights, they are even more vulnerable to exploitation, and it is harder for them to exercise their rights.

Whether migrants that posses a temporary status and progress through the illegalization process, are more likely to encounter exploitation in the underground sector is indicative of further research. For example, if a temporary worker surpasses his or her work visa, is he or she most likely to end up in an exploitable position. Although the worker was "legal" at one point, temporary foreign workers often have limited knowledge of the law. Thus, when the worker becomes illegalized, they may become more susceptible to exploitation, as they continue to have limited knowledge and the vulnerable position becomes normalized. They may continue to believe that they have no labour and employment rights, or that they cannot do anything about the exploitation. A survey by the Workers' Action Centre (2011), revealed that some workers do 
not know that they have any rights at work. Others assess the cos and pros regarding speaking up about work related violations, such as unpaid wages. The survey revealed that one in five workers did not speak up about unpaid wages (Workers’ Action Centre (2011).

\section{2 The Sanctuary Movement}

In 2011, the city of Toronto reached 2,855,085 residents (Toronto Police Service, 2011). The residents have a full membership to the state and can fully participate in the urban civic community. However, it was estimated that 40,000 to 250,000 illegalized immigrants reside in Toronto (Hannan, 2015; Goldring, Berinstein \& Bernhard, 2009), but they are unable to enjoy the same membership and civic life as "legal" residents. The omnipresence and exclusionary policies towards illegalized immigrants in Toronto sparked activists to plea for a Sanctuary City (No One is Illegal, 2016; the Social Planning Toronto, 2013). The network demanded that every person, regardless of his or her immigration status, should be able to live in the city without the fear of being abused, detained and/or deported (Bauder, 2015). It also argued that immigrants should be able to access municipal services, be recognized as contributing members of the city and be able to participate in 'urban civic life' (Bauder, 2015).

Similarly, the No One is Illegal political movement challenged the state's power that serves to distinguish between citizens and non-citizens (Nyers, 2010). A key question that derived from the latter movement is what criteria, if any, should be used in order to dictate a political membership to a state (Nyers, 2010). In 2004, the No One is Illegal movement also commenced the 'Don't Ask Don't Tell' campaign (No One is Illegal, 2016). The campaign demanded municipal services to refrain from requesting a person's immigration status (No One is Illegal, 2016). It pursued access to municipal services for illegalized immigrants, without the fear of detention or deportation (No One is Illegal, 2016). A 'Don't Ask Don't Tell' policy has 
the ability to improve the security and quality of life for many illegalized immigrants (No One is Illegal, 2016). It is also a political statement, as it contradicts with federal immigration law. It undermines the laws and provides legalized immigrants with access to services, as well as a membership the community. ${ }^{4}$

Toronto and Hamilton became Sanctuary Cities in 2013 and 2014, respectively (No One is Illegal, 2016). In a way, a Sanctuary City is “... a space in which formal notions of citizenship have been challenged..." (Nyers \& Rygiel, 2012, p.129). The city is challenging strict federal immigration laws (from the ground up), as they are producing a class of illegalized immigrants, without any access to essential services. Although these groups are undermining immigration law, they are not transforming it (Ridgley, 2008). Sanctuary Cities provide illegalized immigrants access to municipal services, as it is under their jurisdiction, but they cannot surpass their powers. They cannot create pathways to citizenship or change laws that are essentially creating an environment that is producing illegalized immigrants. Nevertheless, by undermining state law, they are providing a membership to the space - to every person irrespective of his or her immigration status (Ridgley, 2008). Every person belongs to the city, and thus they should actively be included in the social and political sphere (Bauder, 2015).

A Sanctuary City is possible, as it is not within the jurisdiction of the City of Toronto to monitor illegalized immigrants (Brillinger, 2015). The City is not supposed to request information regarding immigration status, unless it is required by another order of government (Brillinger, 2015). In Toronto, municipal services are available to all residents, regardless of their immigration status (Siemiatycki, 2015; Bauder; 2015). Illegalized immigrants can access

\footnotetext{
${ }^{4}$ Other movements: In 2006, the Toronto District School Board affirmed all student's right to education (No One is Illegal, 2016).
} 
services, such as health clinics, schools, emergency shelters, recreational programs and food banks (Hannan \& Bauder, 2015).

Although illegalized immigrants are permitted to use municipal services, it is still difficult for them to access the services (Hannan \& Bauder, 2015). First, due to a lack of awareness and/or training, many municipal employees do not know that they can assist illegalized immigrants, thus they often ask for an immigration status (Hannan \& Bauder, 2015). In fact, the FCJ Refugee Centre conducted an audit in order to determine whether municipal services are complying with the Sanctuary City policies (Brillinger, 2015). The audit concluded that many front-line staff had inconsistent knowledge regarding the Sanctuary City policies (i.e. high-turnover rates means that employers are not aware of these policies) (Brillinger, 2015). As a result, many illegalized immigrants are denied access, even though they are eligible for the cityfunded services (Brillinger, 2015).

In addition, in a Sanctuary City illegalized immigrants cannot access provincial or federal services. This means that illegalized immigrants cannot access services such as welfare and healthcare, Employment Insurance (EI), Ontario Works or the Ontario Disability Support Program (Hannan \& Bauder, 2015). Worker's rights and equitable employment is, in turn, limited for illegalized immigrants (Hannan \& Bauder, 2015). A Sanctuary City Mandate does not have policies in place to address labour and employment protection, but some labour and employment rights “extend” to illegalized workers (Workers' Action Centre, 2011).

For example, in Ontario illegalized workers are protected under the Employment Standards Act, which covers all non-unionized workers (Workers' Action Centre, 2014). This means that if an illegalized worker is paid below provincial and federal minimum wage, the worker can file a claim to the Ministry of Labour (Workers' Action Centre, 2014). Although the 
Ministry does not typically inquire about an immigration status or share information to federal authorities, illegalized workers still risk being detained and deported (Workers' Action Centre, 2014). In theory, illegalized workers attain basic labour and employment rights, but employers can keep workers in substandard conditions, as employers often threaten to call immigration officials (Workers' Action Centre, 2011).

Researchers have started to advocate for a Sanctuary Province in Ontario (Hannan \& Bauder, 2015). Hannan and Bauder (2015), argue that provincial and territorial governments have various options that can serve to challenge state laws that are producing illegalized immigrants. Provincial and territorial governments can also implement various policies, programs and services that can enhance "equitable employment, social participation and economic advancement" for illegalized immigrants (Hannan \& Bauder, p.13). This, in turn, could also extend access to illegalized immigrants in neighboring cities and secure labour and employment rights for every worker, irrespective of his or her immigration status. Currently, there is no Sanctuary Province in Canada, thus there is no precedent that could be used. As labour and employment laws are under provincial jurisdiction, a Sanctuary Province in Ontario is taking steps in the right direction. If Ontario becomes a Sanctuary Province, it could challenge and undermine federal laws that are generating illegalized immigrants. The last section will discuss labour and employment rights, as well as set policy recommendations.

\section{PART IV}

\section{1 Labour and Employment Rights and Recommendations}

It is important for illegalized immigrants to 'know their rights,' in conjunction with living in a space where they are able to exercise their labour and employment rights. Illegalized workers are protected under basic labour and employment laws (as cited in Magalhaes, Carrasco, 
\& Gastaldo 2010). However, many illegalized workers avoid legal protection as they fear that they will be exposed to authorities (as cited in Magalhaes, Carrasco, \& Gastaldo 2010). In theory, illegalized immigrants can seek legal protection and are not excluded from: 1) the Employment Standard Act (ESA); 2) the Human Rights Code; and 3) the Workplace Safety and Insurance Act; and 4) the Occupational Health and Safety Act (OHSA) (as cited in Magalhaes, Carrasco, \& Gastaldo 2010). For example, in Ontario, in accordance with the Occupational Health and Safety Act, illegalized immigrants can file anonymous complaints regarding unhealthy or unsafe working conditions (as cited in Magalhaes, Carrasco, \& Gastaldo 2010). Further, illegalized workers are protected under the $E S A$, which covers all non-unionized workers (Workers' Action Centre, 2011). The Act provides rules regarding minimum wage, cash payments, weekly hours, overtime, vacation, public holidays, termination notice or pay, and severance pay (Workers' Action Centre, 2014). In accordance with the ESA, the worker can file a claim to the Ministry of Labour (Workers' Action Centre, 2011). Every worker can file a claim, irrespective of the worker's immigration status (Workers' Action Centre, 2014).

The Ministry is not supposed to share information with the authorities (Workers' Action Centre, 2011). Although making a claim is easy (as long as the illegalized worker knows his or her rights), a person making the claim may be asked to present himself or herself at the meeting. This form of resolution gives employers the power to call immigration authorities (Workers' Action Centre, 2011). Although some claimants are provided with an opportunity to call instead of presenting himself or herself in person (Workers' Action Centre, 2011), another feasible resolution might be to ensure that every illegalized worker that makes a claim is provided with this opportunity. By allowing illegalized immigrants to use electronic communication instead of presenting himself or herself in person, it will ensure anonymity. It will also disrupt the power 
imbalance between the employer and illegalized worker, as employers often threaten to call immigration officials.

In Canada, welfare policy is formed by federalism (Shields, 2004). The federal government is responsible for Employment Insurance (Shields, 2004). As illegalized workers are not members of the political state, they are not eligible for Employment Insurance (Worker's Action Centre, 2011). Extending EI to illegalized immigrants is unlikely to line-up with a neoliberal rhetoric. Over the last decade, employment insurance has become more robust. The length of time to received EI has decreased, the premium has increased, and the eligibility criteria has become more stringent (Shields, 2004). Not extending EI to non-citizens, may be justifiable. However, not extending workers with enforceable labour rights and equitable employment has no justification. If a worker is participating in the labour market and being used for his or her labour, then policies ought to be in place, in order to reduce the likelihood of exploitation.

\section{2 Policy Recommendations}

Many employers know that workers are unaware of their rights, which allows employers to keep illegalized workers in substandard conditions, and if an illegalized worker attempts to assert his or her rights, employers often threaten to call immigration authorities (Workers' Action Centre, 2011). There ought to be accountability for employers, specifically if the employer calls immigration authorities on the illegalized worker for asserting his or her rights (Workers Defense Project, 2013). Another important change that should be made is for the Ministry of Labour to inspect a higher number of workplaces. Currently, the Ministry of Labour inspects less than one percent of Ontario's 370,00 workplaces (Workers' Action Centre, 2011). The Ministry should inspect a higher percentage of workplaces, specifically precarious and part-time jobs. It should 
not be a complaint driven system, as many workers that are likely to be exploited may not know their rights and may not know how to navigate the system.

The following are policy recommendations, which could enhance the labour and employment rights for illegalized workers. Equitable employment is key. Although critics often argue that they do not want to "reward queue jumping," equitable employment is not a reward. It should be a minimum standard for every human being, irrespective of his or her immigration status. Employers and the state should not benefit from the vulnerability of an illegalized worker.

\section{Sanctuary Province in Ontario}

I.1. Due to the growth and new regulations of the TFWP, it is likely that some temporary foreign workers will remain in Canada, once their work visas expire. Therefore, it is important to generate a proactive solution that will protect illegalized immigrants.

Ontario should become a Sanctuary Province, as labour and employment rights are under provincial jurisdiction. A Sanctuary Province could also provide illegalized immigrants with access to other provincial services, such as a driver's license. More importantly, a Sanctuary Province in Ontario will also extend access to neighboring cities (for illegalized immigrants that do not reside in Toronto or Hamilton).

\section{Accountability for Employers}

II.1 Employers need to be held accountable for the exploitation of workers. If an illegalized person is detained, authorities should ensure that the worker is able to carry through with the due process, prior to being deported. For example, ensuing that the worker receives full remuneration for any unpaid wages.

II.2 Illegalized immigrants should be able to exercise their rights and employers should be held accountable for retaliating against the illegalized worker (typically by informing 
immigration authorities). If it is proven that the employer retaliated against the illegalized worker, then there should be a sanction against the employer (Cho \& Smith, 2013). In addition, employers that are found guilty of violating the ESA, face little cost (Workers' Action Centre, 2011). They only have to pay the wage that they should have initially paid and sometimes the employee receives less money (Workers' Action Centre (2011). In order to deter employers from violating the ESA, harsher sanctions should be set.

\section{Superior Working Conditions}

III.1 The Ministry should commit to inspecting more precarious and "low skilled" jobs. The The Ministry only inspects less than one percent of Ontario's 370,00 workplaces (Workers' Action Centre, 2011). Being a complain driven system means that it relies on the worker to make a complaint, but many do not know that they have rights or how to navigate the system. The Ministry should not rely on the worker to make a complaint.

III. 2 The state should provide a mandatory orientation for temporary foreign workers. It should be independent from the employer. The orientation should provide the workers with information regarding their rights and resources in case he or she experiences an unsafe or unhealthy environment, or exploitation. This is important, as some of these workers may become illegalized, thus they will be aware of their rights. This will also provide illegalized immigrants with resources that they can contact, in case of a workplace violation. In accordance with a survey by the Workers' Action Centre (2011), $63 \%$ of the respondents stated that they needed help in order to make a complaint. Thus, providing the workers with an overview of the system is important. This might influence a worker's ability to file a report. 


\section{PART V}

\section{V.1 Conclusion}

In Mexico, a man, his pregnant wife and three children trespasses onto my grandmother's vacant property. At first, my grandmother asked them to leave. However, as the family was seeking shelter, she granted them temporary permission to stay. She had two rules: 1) the man had to maintain the property; and 2) he had to ensure that no other person trespassed onto the property. As his parents moved into the house, my grandmother asked the family to move out. With nowhere to go and as the man felt that they had a right to stay, he attained a lawyer. He wanted to pursue ownership of the property. The story is twofold: The man and his family do not have a formal right to stay or a right to the property, but, nonetheless, they still have human rights. Whether they can exercise these rights depends on whether they are in a position to exercise them.

I typically refrain from sharing the ending of the story. I want the audience to see past the question of whether an illegalized immigrant should have a right to remain in Canada. Instead I want the audience to focus on whether an illegalized immigrant should have human rights while they remain in Canada. When I first started sharing this narrative with my colleagues, I did not know the ending of the story. It made me think critically of the profound issues at hand, instead of focusing on whether the family should or should not keep the property. As I prepared for another presentation, I asked my mother "what happened to the man?" At the time, my mother was a young girl. However, she recalls that the man and family were evicted from the property. A couple of weeks later, the man's sister showed up at my grandmother's house and begged my grandmother to refrain from pressing charges against her brother. As the sole provider of his family, she did not want him to go to jail. My grandmother did not press 
charges. I will never know why my grandmother made that decision. I want to believe it was because she knew that he did not make a fully voluntary decision (when he trespassed onto her property). By giving him a second chance, she treated him like a human being.

This MRP takes a critical perspective on the neoliberal policies that illegalizes immigrants. The state as well as capitalists want and profit from illegalized immigrants. The state is fully aware that these policies are creating a pool of flexible and exploitable workers. Nevertheless, they are continuing to expand the TFWP (with stringent rules and no pathways to permanent residency). This may force temporary foreign workers underground and into precarious and exploitable jobs. The state has implemented sanctions against employers. Although they are supposed to "protect" illegalized workers and deter employers from hiring them, they are failing. Border control is also failing, as most illegalized immigrants enter through legal avenues (Bauder \& Shields, 2015; Hannan, 2013; Goldring, Beirstein \& Bernhard, 2007) and the state knows that. De Genova (2013) contends that strict law enforcement is merely for show. The purpose of law enforcement and strict immigration rules is to undermine the state's role in generating illegalized immigrants.

As illegalized workers enter the underground, they become vulnerable to exploitation. The omnipresence of illegalized immigrants in Toronto sparked activists to plea for a Sanctuary City in Toronto (No One is Illegal, 2016; the Social Planning Toronto, 2013). Although it is a significant milestone, it cannot fully improve working conditions for illegalized workers. This is due to the fact that labour and employment rights are under provincial jurisdiction. In order to improve labour and employment rights for illegalized immigrants, Ontario should become a Sanctuary Province. The justification for this plea is as following: Labour and employment rights should protect every worker, irrespective of his or her immigration status. Labour and 
employment laws should not be used as a vehicle to defend sovereignty or dictate membership to a state. 


\section{References}

Aguilera, M.B., \& Douglas S. M. (2003). Social Capital and the Wages of Mexican Migrants: New Hypotheses and Tests. Social Forces, 82 (2), 671-701. doi: 10.1353/sof.2004.0001

Amin-Khan, T. (2015). Security and Its Impacts on Migrants and Refugees. In Bauder, H., \& Shields, J. (Eds.), Immigrant Experiences in North America: Understanding Settlement and Integration (118- 143). Toronto: Canadian Scholar's Press.

Austin, C., \& Bauder H. (2010). Jus Domicile: A Pathway to Citizenship for Temporary Foreign Workers? (RCIS Working Paper No. 81). Retrieved from http://www.geography.ryerson.ca/hbauder/Immigrant\%20Labour/wp81.pdf

Barrett, J. (2013, March 17). Penalties rare for companies that hire illegal migrant workers, lawyers say. Vancouver Sun. Retrieved from http://www.vancouversun.com/Penalties + rare + companies + that + hire + illegal+migrant+workers+lawyers $/ 8117231 /$ story.html

Bauder, H. (2014). Why We Should Use the Term 'Illegalized' Refugee or Immigrant” A Commentary. International Journal of Refugee Law, 00 (00), 1-6. doi: $10.1093 /$ ijrl/eeu032

Bauder, H. (2011). Immigration Dialectic: Imagining Community, Economy, and Nation. Toronto: University of Toronto Press. Retrieved from https://books.google.ca/books?hl=en\&lr=\&id=DLnxh802hYkC\&oi=fnd\&pg=PR9\&dq=B auder, + H. $+(2011) .+$ Immigration+Dialectic:+Imagining + Community,+ Economy, + and $+\mathrm{N}$ ation.++\%09Toronto:+University+of+Toronto+Press.\&ots=M0sHDKSUNI\&sig=_7_26 Om7jt6XgvdHCDuwzIzBgog\#v=onepage\&q\&f=false

Bauder, H. (2015). Possibilities of Urban Belonging. Antipode Foundation Ltd. 48(2), 252-271. doi 10.1111/anti.12174 
Berinstein, C., Jean, M., Nyers, P., Wright, C., \& Zerehi, S. S. (2006). Access Not Fear: NonStatus Immigrants \& City Services.

Bernhard, J.K., Goldring, L., Young, J., Berinstein, C. \& Wilson, B. (2007). Living in Precarious Legal Status in Canada: Implications for the Well-Being of Children and Families. Early Childhood Education Publications and Research, 24 (2), 101-114. Retrieved from igital.library.ryerson.ca/islandora/object/RULA\%3A168

Bloch, A., Kumarappan, L., \& Mckay, S. (2014). Employer sanctions: The impact of workplace raids and fines on undocumented migrants and ethnic employers. Critical Social Policy, 132 151. doi: $10.1177 / 0261018314545600$

Brillinger, C. (2015). Access to City Services for Undocumented Torontonians: Progress of the Access T.O Initiative. Retrieved from http://www.toronto.ca/legdocs/mmis/2015/cd/bgrd/backgroundfile-85779.pdf

Solidarity City (2013). Towards a Sanctuary City: Assessment and recommendations on municipal service provision to undocumented residents in Toronto.

Burke, M., Mooers, C., \& Shields, J. (2000). Critical Perspective on Canadian Public Policy. In Burke, M., Mooers, C., \& Shields, J. (Eds.), Restructuring and Resistance: Canadian Public Policy in an Age of Global Capitalism (11-23). Halifax: Fernwood Publishing. Carens, J.H. (1987). Aliens and Citizens: The Case for Open Border. The Review of Politics 49 (2). Retrieved from http://links.jstor.org/sici?sici=00346705\%28198721\%2949\%3A2\%3C251\%3AAACTCF\%3E2.0.CO\%3B2-I

Criminal Intelligence Service Canada (2005). 2005 Annual Repot on Organized Crime in Canada Retrieved from http://publications.gc.ca/collections/Collection/PS61-1-2005E.pdf 
CIS NEWS (2015). Potential Options To Remain In Canada For TFWs Facing Uncertain Future. Retrieved from http://www.cicnews.com/2015/03/potential-options-remain-canada-tfwsfacing-uncertain-future-034744.html

Dauvergne, C. (2008). Making People Illegal: What Globalization Means for Migration and Law. New York: Cambridge University Press.

De Genova, N. (2013). Spectacles of migrant 'illegality': the scene of exclusion, the obscene of inclusion. Ethnic and Racial Studies, 31-41. doi: 10.1080/01419870.2013.783710

De Genova, N. P. (2002). Migrant "Illegality" and Deportability in Everyday Life. Annu. Rev. Anthropol, 31, 419-447. doi: 10.1146/annurev.anthro.31.040402.085432

Dobrowolsky, A. (2013). Nuancing Neoliberalism: Lessons Learned from a Failed Immigration Experiment, Springer Science + Business Media, 14, 197-218. doi: $10.1007 / \mathrm{s} 12134-012-0234-8$

Duvell, F. (2011). Paths into Irregularity: The Legal and Political Construction of Irregular Migration. European Journal of Migration and Law, 13, 275-295. doi: $10.1163 / 157181611 \times 587856$

Kallen, E. (2003). The Human Rights Perspective: International Human Rights. In Macmillan, P. (Eds.), Social Inequality and Social Injustice: A Human Rights Perspective (6-14).

Foster, J. (2012). Making Temporary Permanent: The Silent Transformation of the Temporary Foreign Worker Program. A Canadian Journal of Work and Society, 19, 22-46.

Gabriel, C. (2006). A Question of Skills: Gender, Migration Policy and the Global Political Economy. In Pijl V. D. K., Assassi, L., \& Wigen, D. (Eds.), Global Regulation: Managing Crises After the Imperial Turn (162-176). New York: Palgrave Macmillan. 
Gordon, J (2006). Transnational Labour Citizenship. Southern California Law Review, 80, 503588. Retrived from http://papers.ssrn.com/sol3/papers.cfm?abstract_id=943061

Goldring, L., Berinstein, C. \& Bernhard, J.K. (2009). Institutionalizing precarious migratory status in Canada. Citizenship Studies, 13 (3), 239-265. doi:10.1080/13621020902850643

Government of Canada. (2016a, August). Immigration and Refugee Protection Act. Retrieved from http://laws.justice.gc.ca/eng/acts/i-2.5/fulltext.html

Government of Canada. (2016b, June). Entry/Exit initiative. Retrieved from http://news.gc.ca/web/article-en.do?nid=1085449

Government of Canada. (2015, February). Temporary Foreign Workers Program. Retrieved from http://www.cic.gc.ca/english/resources/publications/employers/temp-foreign-workerprogram.asp

Pastor, M., \& Alva, A. (2004). Guest Workers and the New Transnationalism: Possibilities and Realities in an Age of Repression. Social Justice, 31(1-2), 92- 112. Retrieved from http://cjtc.ucsc.edu/docs/Guest_Workers_Transnationalism.pdf

Hannan, C.A. (2013). Employment Equity and Access to Social Welfare for Illegalized Immigrants: An Inclusive Approach That Also Makes Economic Sense (RCIS Research Brief No. 2013/1). Retrieved from http://www.ryerson.ca/content/dam/rcis/documents/RCIS_WP_Hannan_No_2013_1.pdf Hannan, C. A. (2015). Illegalized Migrants. In Bauder, H., \& Shields, J. (Eds.), Immigrant Experiences in North America: Understanding Settlement and Integration (144-165). Toronto: Canadian Scholar's Press. 
Hannan, C.A. \& Bauder, H. (2015). Towards A Sanctuary Province: Policies, Programs, and Services for Illegalized Immigrants' Equitable Employment, Social Participation and Economic Development (RCIS Research Brief No 2015/3). Retrieved from http://www.ryerson.ca/content/dam/rcis/documents/RCIS_WP_Hannan_Bauder_No_201 5_3.pdf

Hannan, C.A., Bauder, H. \& Shields, J. (2015). 'Illegalized' Migrant Workers and the Struggle for a Living Wage. A Journal of Critical Social Research, 27, 109-136.

Haque-Hausrath, S. (2008). Border Crossing. Retrieved from http://www.nohumanbeingisillegal.com/Home.html

Harvey, D. (2007). Neoliberalism as Creative Destruction. $A N N A L S$, 610, 22-44.

Harvey, D. (2005). A Brief History of Neoliberalism. Oxford University Press. New York: Oxford University Press.

Khandor, E., McDonald, J., Nyers, P., Pravaz, N., Wilson B., Wright., C. (2004). The Regularization of Non-Status Immigrants in Canada 1960-2004: Past Policies, Current Perspectives, Active Campaigns.

Leach, B. (2013). Canada's Migrants without History: Neoliberal Immigration Regimes and Trinidadian Transnationalism. International Migration, 51(2), 32-45. doi: 10.1111/imig.12019

Magalhaes, L. Carrasco, C. \& Gastaldo, D. (2010). Undocumented Migrants in Canada: A scope literature review, health, access to services, and working conditions. J Immigr Minor Health, 12 (1), 132-151. doi: 10.1007/s10903-009-9280-5.

Marsden, S. (2011). Assessing the Regulation of Temporary Foreign Workers in Canada. Osgoode Hall Law Journal, 49 (1), 39-70. Retrieved from http://digitalcommons.osgoode.yorku.ca/cgi/viewcontent.cgi?article=1072\&context=ohlj 
Mehta, C., N. Theodore, I. Mora, and J. Wade (2002). Chicago's Undocumented Immigrats: An Analysis of Wages, Working Conditions, and Economic Contributions. UIC Centre for Urban Economic Development. Retrieved from http://www.williamperezphd.com/articles/mehta-theodore-mora-wade-2002.pdf

Social Policy, Analysis \& Research (2013). Newcomer Demographics. Toronto. Retrieved from http:/www.toronto.ca/legdocs/mmis/2013/cd/bgrd/backgroundfile-55335.pdf No One is Illegal (2016). No one is Illegal-Toronto. Retrieved from http://toronto.nooneisillegal.org

Nyers, P. (2010). No One is Illegal Between City and Nation. Studies in Social Justice, 4 (2), 127-143.

Paradis, E., Novac, S., Sarty, M., \& Hulchanski, D. J. (2008). Better Off in a Shelter? A Year of Homelessness \& Housing among Status Immigrant, Non-Status Migrant, \& CanadianBorn Families. Centre for Urban and Community Studies, 1-89. Retrieved from http://www.urbancentre.utoronto.ca/pdfs/researchbulletins/ParadisetalBetterOffinaShelter 7-2008.pdf

Ridgley, J. (2008). Cities of refuge: Immigration enforcement, police, and the insurgent genealogies of citizenship in US sanctuary cities. Urban Geography, 29 (1), 5377.

Root, J., Gates-Gasse E., Shields, J. \& Bauder, H. (2014) Discounting Immigrant Families: Neoliberalism and the Framing of Canadian Immigration Policy Change (RCIS Working Paper no. 2014/7).

Ruth Milkman et al. (2010). Wage Theft and Workplace Violations in Los Angeles: The Failure of Employment and Labor Law for Low-Wage Workers. Institute for Research on Labor and Employment, 46-48. 
Sassen, S (2006). Cities in a World Economy. California: Pine Forge Press.

Sedef, A.K. (1999). Neo-Liberalism, State Restructuring and Immigration: Changes in Canadian Policies in the 1990s. Journal of Canadian Studies, 34 (2), 31-56. Retrieved from http://search.proquest.com/openview/8431fd308df94c27ce2c12508ab3a026/1?pqorigsite $=$ gscholar $\&$ cbl $=1818991$

Sharma, N. (2015). Immigrant Status and the Legalization of Inequality. In Bauder, H., \& Shields, J. (Eds.), Immigrant Experiences in North America: Understanding Settlement and Integration (204-222). Toronto: Canadian Scholar's Press.

Siemiatycki, M. (2015). Continuity and Change in Canadian Immigration Policy. In Bauder, H., \& Shields, J. (Eds.), Immigrant Experiences in North America: Understanding Settlement and Integration (93-117). Toronto: Canadian Scholar's Press.

Social Planning Toronto (2013). Accessing Community Programs and Services for Non-Status Immigrants in Toronto: Organizational Challenges and responses. United Way Member Agency.

Smith, R. \& Cho, E.H. (2013). Worker's Rights on ICE: How Immigration Reform Can Stop Retaliation and Advance Labor Rights. NELP. Retrieved from: http://www.nelp.org/page/-/Justice/2013/Workers-Rights-on-ICE- RetaliationReport.pdf?nocdn=1

Standing, G. (2001). The Precariat: The New Dangerous Class. London: Bloomsbury Academic. The United Nations. (1948). Universal Declaration of Human Rights. Retrieved from http://www.un.org/en/universal-declaration-human-rights/ 
Toronto Police Service (2011). Planning for the Future Scanning the Toronto Environment.

Retrieved from http://www.torontopolice.on.ca/publications/files/reports/ 2011envscan.pdf

Turner, J. (2012, July 2). Company fined \$12,000 in illegal worker bust. Toronto Sun. Retrieved from http://www.someaddress.com/full/url/

Walia, H. (2010). Transient Servitude: migrant labour in Canada and the apartheid of citizenship. Race \& Class, 52 (1), 71-84. doi: 10.1177/0306396810371766

Workers' Action Centre (2011). Unpaid Wages, Unprotected Workers: A Survey of Employment Standards Violations. Retrieved from http://www.workersactioncentre.org/wpcontent/uploads/2011/12/pb_unpaidwagesunprotectedworkers_eng.pdf

Workers' Action Centre (2014). Undocumented? No Status? No Work Permit? Retrieved from http://www.workersactioncentre.org/wp-content/uploads/dlm_uploads/2014/09/fsundocumented-eng.pdf

Workers Defense Project (2013). Build a Better Nation: A Case for Comprehensive Immigration Reform. Retrieved from: http://workersdefense.org/IMMIGRATION\%20wdp\% 20color\%20FINAL.p df

Arat-Koc, S. (1999). Neo-Liberalism, State Restructuring and Immigration: Changes in Canadian Policies in the 1990s. Journal of Canadian Studies, 34 (2), 31-56.

Shields, John (2004). No Safe Haven: Work, Welfare, and the Growth of Immigrant Exclusion. (CERIS Working Paper No. 22). Retrieved from http://ceris.ca/wpcontent/uploads/virtual-library/Shield_2004.pdf 